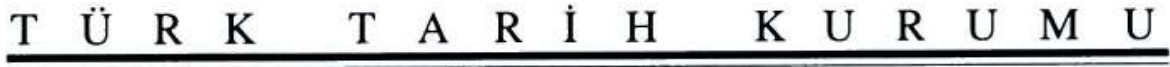 BELLETEN
}

\section{ERKEN SINOP YERLEŞMELERI}

\section{ÖZDEMIR KOÇAK*}

Sinop, Karadeniz Bölgesi'nin önemli liman kentlerinden birisidir. Burası Kuzey Anadolu Dağları tarafından ikiye bölünen ve farklı coğrafi özellikler gösteren bir bölgedir (Harita 1). Bu çalışmamızda, Sinop'un en eski dönemlerinden başlayarak Roma egemenliği sonuna kadar olan yerleşmelerini ele almaktayı.

Burada, Sinop'da yapılan birkaç bilimsel araşturma ve kazının yanısıra bölgede sürdürdüğümüz araştırmalar ve müze çalısmaları sırasında edindiğimiz bilgiler de değerlendirmelerimizde önemli bir katkı sağladı ${ }^{1}$. Bu bölgede yapılan çalışmaların başlıcaları: Ch. Burney ${ }^{2}$, M. A. Işsın ve Ş. Dönmez gibi araşurmacıların bilimsel nitelikli yüzey araşturmaları ve buradaki malzemelerle ilgili değerlendirmeleri ile, E. Akurgal'ın Sinop'da yaptığı kazılar$\mathrm{dir}^{5}$. Bunun yanında Karadeniz Ticari Projesi çerçevesinde bölgede çalışan bir ekibin değerlendirmeleri de gözönüne alınmışur ${ }^{60}$.

• S. Ü. Fen-Edebiyat Fakültesi, Eskiçağ Tarihi Anabilim Dah, Araşturma Görevlisi Dr.

1 Prof. Dr. M. Özsait başkanlığında 1990 yılından bu yana sürdürdüğümüz "Orta Karadeniz Bölgesi Yüzey Araşurmaları: Amasya, Tokat, Samsun ve Ordu Illlerinde" isimli çalışmalanmız, bōlgenin yerleşim ōzelliklerinin yanısıra, coğrafi ve ekonomik yapı òzelliklerini de anlamamız bakımından oldukça yararlı olmuştur. Sinop da, genel õzellikleri bakımından Orta Karadeniz ve Bau Karadeniz Bölgeleri arasında bir geçiş bölgesi görünümündedir.

${ }^{2}$ Burney 1956, 179 vdd.

${ }^{3}$ Işın 1998, 95 vdd.

'Dönmez 2000, 229 vdd.

5 Akurgal 1956, 47 vdd.; Akurgal-Budde 1956, 4 vdd. Ayrica bkz. Erzen 1956, 3 vdd.

${ }^{\circ}$ Doonan vd. 1998, 367; Doonan vd. 1999, 364 vdd.; Hiebert 1997, 377. 
Sinop yerleşmelerini iki kısımda inceledik. İlk önce, genel yerleşim özellikleri ve bunun çerçevesinde Sinop yerleşmeleri üzerinde durduk. Daha sonra, Sinop'da araştırılmış yerleşmelerden yararlanarak yerleşmelerdeki kültürler, bu kültürler arasındaki ilişki ve sürekliliği ortaya koymaya çalıştık.

\section{Yerleşim Özellikleri}

Önceleri Karadeniz kıyılarındaki yerleşim şekilleri ile ilgili farklı düşünceler vardı. Bu düşünceler de, genel olarak bölgedeki araşturmaların yetersizliğinden kaynaklanmaktaydı. Nitekim, 1940'lı yıllarda E. Forrer, Karadeniz kıyılarında höyük tipi yerleşmelerin çok sık bulunamayacağı düşüncesindeydi. Ona göre, bu bölgede daha çok ormanlık bölgeye uygun, birbirinden uzak mesafelerde, yamaçlar üzerine kurulmuş yerleşmeler bulunmalıdır. Araşurmacıya göre bölgede ahşap malzemenin bol kullanıldığı küçük köy tipi yerleşmelerin yoğun olması gerekmektedir ${ }^{7}$. Aynı şekilde, K. Bittel da, bu bölgedeki höyüklerin kuzey sınırını, Amasya ve Çorum'dan daha yukarıya çıkarmamaktaydı ${ }^{8}$. Ancak, yapılan araşturmalarla bunun doğru olmadığını, biraz aşağıda da değinileceği gibi, özellikle bölgedeki derin nehir vadilerinde ve sahildeki geniş ovalarda yoğun bir höyük yerleşiminin olduğu anlaşlacaktur'.

${ }^{7}$ Forrer 1927, 27 vdd

${ }^{8} \mathrm{~K}$. Bittel, Praehistorische Forschung in Kleinasien, İstanbul, 1934, 120 vdd. 1926'larda H. von der Osten'ın yapuğı araşurmalarda, bölgede az da olsa erken dönemleri veren yerleşmeler bilinmekteydi. Ayrıntulı bilgi için bkz. H. H. von der Osten, Explorations in Central Anatolia. Season of 1926. Chicago, 1929; Th. Macridy, "Une Citadelle Archaique du Pont". Mitteilungen der Vorderasiatischen Gesellschaft, 4 (1907), 167-175, fig. 1-26, 169 vdd. R. Naumann da, höyüklerin sayılarının İç Anadolu'dan kıyılara doğru giderek azaldığını öne sürer. Bkz. R. Naumann, Eski Anadolu Mimarlı̆ı, çev. B. Madra, Ankara, 1985, 214.

${ }^{9}$ K. Kökten- T. Özgüç, "Samsun'da Prehistorik Araşurmalar (1)". Ülkü, Halkevleri ve Halkodaları Dergisi, XV/89 (1940), 413-419, 414 vd. T.Özüç. Samsun, Çarşamba, Bafra ve Sinop'ta yerleşmeye uygun kıyı ovaları ve küçük nehir deltaları bulunduğunu belirterek; bu görüşün, bütün Karadeniz kyyları için geçerli olamayacağını bildirmektedir. Bu konuda bkz. Özgüç 1948, 394 vd. Ayrıca bkz. Kökten vd. 1945, 364, 396 vd.; I. K. Kökten. Anadolu'da Prehistorik Yerleşme Yerlerinin Dağılışı Üzerine Bir Araşturma", DTCFD, X/3-4 (1952), 167-207. hrt.1-4, 192. Nitekim, E. Y. Bostancı, Prehistorik yerleşmelerle ilgili değerlendirmeler yaparken, bu nehir vadilerinin, aym zamanda doğal prehistorik yollar olduğunu belirtmektedir. Ona göre, Gökırmak kültürlerinin, Orta ve Güney Anadolu'da da mevcut olması dolayısıyla, Kızılırmak ve Yeşilırmağın kuzeyi güneye birleştiren, doğal iki prehistorik yol olduğu neticesi çıkmaktadır. Bunun sonucu olarak da, Gökırmak Vadisi'ndeki Paleolitik ve Bakırçağ (ITT II) kültürlerinin, Kızılırmak ve Gökırmak yoluyla bu vadiye geldiğini düşünmektedir. E. Bostancı, "Gökırmak Vadisi'nde Prehistuvar Araşturmalanı ve Yeni Paleolitik Buluntular", DTCFD, X/1 (1952), 137. 143, 140, 142. 
K. Kökten, sahil boyu araşurmaları sırasında, Samsun 'dan itibaren Çarşamba Deltası doğusuna kadar olan alanın, verimli; delta doğusundan Ordu çevresine kadar şüpheli ve Ordu doğusundan Rize'ye kadar boş bir netice vermesi ve Kızılırmak deltasından batyya, yani Sinop dolayına silik bir sıçrayıs göstermesinin, Samsun'un arkeolojik yönden önemini arttırmasına kanıt olarak göstermektedir ${ }^{10}$.

Karadeniz Bölgesi'nin kuzey kesimlerindeki yerleşim yerlerini, güneyden kuzeye doğru uzanan nehirlerin açtığı derin vadilerde, K. Kökten'in de söylediği gibi, Kuzey Anadolu sıradağlarının arasından uzanan tarihi doğal yol güzergahında aramak gerekmektedir. Son yllarda yapılan araştırmalar, bölgenin en erken dönemlerden itibaren ve yaygın olarak yerleșime sahne olduğunu göstermektedir ${ }^{11}$. Özellikle, ormanlık kesimlerde yerleşim yoğunluğunun azalması muhtemelen sosyokültürel yapıyla ilgili olmalıdır ${ }^{12}$. Kıyı kesiminde, yüksek sahadaki yeni yerleșmelerinin çoğunluğu, vadi yamaç ve içlerinde kaynaklara yakın yerlerde toplanmışlardır ${ }^{13}$.

Coğrafi konum ve özellikler bakımından Sinop'la yakın olan Kastamonu da, yerleşim özellikleri bakımından önemli bir yerdir. Burada da, bölgenin

${ }^{10}$ I. K. Kökten, DTCFD, III/5 (1945), 479. Yine buna bağh olarak, K. Kōkten, Yıldızeli ve Artova çevresinin Bakırçağ (IT II-III), Hitit ve Phryg dōnemlerinde Yukarı Kızılırmak boyu ile, kısmen Kangal çevresinden ziyade, Samsun çevresi ve onun güney ve bat hinterlandı yönüne bir bağlantı gösterdiğini öne sürmektedir. Bkz. İ. K. Kökten, "1947 Yılı Tarihöncesi Araşurmaları", Belleten, XII/45 (1948), 223-226, 223. Bu iddiaların, 1940-50'li yıllarda bölgede yapılan araştırmaların yetersizliğinden dolayı gündeme geldiği gözönünde bulundurulmalıdır. Aynı şekilde, 1946 'lı yıllarda T.Özgüç de, bölgenin orta kesimlerinde hōyüklerin olmayışın eski dönemlerde buraların bataklık olmasıyla açıklamaktadır. Bkz. T. Özgüç, "Anadolu"da Arkeoloji Araşurmaları I". Belleten, X/40 (1946), 557-597, 596.

${ }^{11}$ Özellikle, Sinop'da Erfelek, Ordu'da Melet Vadisi ve Kastamonu'da Gōkurmak, Daday, Araç/Ilgaz vadileri çevresinde yapılan araşurmalar, bölgenin yerleşim coğrafyasını vermesi açısından çok ónemlidir. Bu konuda ayrıntulı bilgi için bkz. M. Özsait, "1990 Yilında OrduMesudiye Çevresinde Yapılan Yüzey Araştırmaları", AST, IX (1992), 357-376, 357 vdd.; M. Özsait, "1991Yilı Ordu-Mesudiye Yüzey Araştırmaları", AST, X (1993), 311-330, 311 vdd.; M. Özsait, "1992 Yılı Ordu-Mesudiye Yüzey Araşurmaları", AST, XI (1994), 285-300, 285 vdd.; Işın 1990, 241 vdd.; Işın 1991, 177 vdd.; Işın vd. 1992; Özdoğan vd. 2000, 41 vdd. KavakKaledoruğu'nun içinde bulunduğu ova da bu duruma güzel bir örnektir. Bu ovanın etrafı, büyük dağlarla kaphlı, suyu bol ve yerleşmeye elverişlidir. Bkz. Özgüç 1948, 412; Kökten vd. 1945. 390.

12 Örneğin; Samsun- Bafra arasındaki alan ormanlıkır. Bu yüzden, bu kesimde höyüklerin sayısı oldukça azdır. Özgüç 1948, 418.

${ }^{13}$ A. Özçağlar, "Çarşamba Ovası ve Yakın Çevresinde Araziden Faydalanma", Ankara Üniversitesi Türkiye Coğrafyası Araşurma ve Uygulama Merkezi Dergisi, 3, 1994 (1995), 93-128. $98 \mathrm{vd}$. 
önemli nehirleri olan Gökırmak, Daday, Araç/Ilgaz vadilerindeki yerleşim yoğunluğu açık bir şekilde gözlenmektedir ${ }^{14}$.

Yerleşim yerlerinin seçiminde belirleyici unsurların gözardı edilmediği bir gerçektir. Bir başka deyişle, insanlar yerleşmelerini oluştururken rastlanularla değilde bazı belirleyici unsurlarla hareket etmektedirler. Bu unsurların en başlıcaları: su, toprak, coğrafi konum, tarihi doğal yollar, maden yatakları vb.'dir ${ }^{15}$. Nitekim, bu kesimde yer alan Samsun-İkiztepe ${ }^{16}$ ve Kastamonu Kınık yerleşmeleri ${ }^{17}$ bu özelliklerin hemen bütününü bünyelerinde toplamaktadır.

Durağan'in güneydoğusunda yer alan Uluköy-Çay yerleşmesi de bu yerleşim seçimi ile ilgili güzel bir örnektir (Harita 2; no: 46). Burada Kalkolitik ve İTÇ dönemlerinde yerleşilmiştir ${ }^{18}$. Durağan'ın $7 \mathrm{~km}$. doğusunda ise Durağan-Alaçam karayolu üzerinde arsenik cevherleşmesine rastlanmaktadır ${ }^{19}$. Bu yerleşme aynı zamanda Kızılırmak yakınlarında ve Kızılırmak Vadisi'ne olduğu gibi Durağan-Alaçam yoluna da yakın bir konumdadır (Harita 2; no: 46) ${ }^{20}$.

Özellikle su, toplumsal yaşamın en önemli parçalarından birisidir. Bu yüzden yerleşmelerin kurulmasında su kaynakları ya da verimli nehir vadileri öncelikli tercih sebeplerinden birisi olmuştur. Nitekim Sinop yerleşmelerinin de Sarımsak, Erfelek, Kabala ve Karasu gibi başlıca ırmak vadilerinde ya da su kaynaklarının yakınlarında kurulduğu görülmektedir. Bu durum, özellikle Kalkolitik ve İTÇ yerleşmelerinde daha belirgin olarak gözlenebilmektedir (Harita 2) ${ }^{21}$.

14 Özdoğan vd. 2000, 41 vdd., harita 1.

${ }^{15}$ Sinop'da Durağan kesimi de maden rezervleri bakımından önemli bir yere sahiptir. Bkz. Özbal vd. 2000, 48 vd. c, 63 vdd.

${ }^{16}$ Alkum vd. 1988, 5 vd.; Bilgi 1990, 2; Bilgi 1994, 253 vdd.; Bilgi 1999 a, 43 vd.; Bilgi 1999

${ }_{17}^{17}$ Çınaroğlu 1991, 55 vdd.; Emre-Çınaroğlu 1993, 675; Bilgen 1999, 269 vdd.

${ }^{18}$ Burney 1956, 181.

19 Özbal vd. 2000, 48 vd.

${ }^{20}$ Orta Karadeniz kesiminde, yerleşimlerle ilgili bu tercihleri yansıtan en ònemli merkez İkiztepe'dir. Bkz. Alkum vd. 1988, 1 vdd.

${ }^{21} \mathrm{Bu}$ durum için Samsun-İkiztepe yerleşmesinin konumu ōrnek olabilir. Bu yerleşme, onceleri hem Karadeniz'in ve hem de Kızılırmağın kıyısında yer almaktaydı. Bkz. Alkım vd. 1988, XXV, 5 vd. 
Bu kesimde yer alan önemli yerleşmelerden Kocagöz Höyük, yerleşim özellikleri bakımından önemli bir örnektir. Bu höyük, iki tarafından vadilerle çevrilmiş hâkim bir tepe üzerindedir ve doğusunda verimli Taşmanlı Ovası uzanmaktadır (Harita 2) ${ }^{22}$.

Erken Kalkolitik döneme tarihlenen Kabalı ve Kıran Höyükleri de Kabala Çayı Vadisi'nde yer almaktadırlar. Aynı şekilde, Sinop'daki başlıca yerleşmelerden Habuhaş Tepe, Kahkül Tepe, Üvez Tepe, Gavur Tepe Erfelek Çayı kenarında olan yerleşmelerdir. Cimbektepe de Kabalı Çayı Vadisi'ne hâkim bir yamaçtadır (Harita 2; Levha I: 1) ${ }^{23}$.

İTÇ’ın sonlarında başlayan siyasal ve ekonomik değişimler, OTÇ/STÇ'da en üstdüzeye ulaşmıştır. Sonuçta, insanların birarada yaşama ihtiyaçlarının daha da artması, o dönemin küçük kentlerinin ortaya çıkmasına neden olmuştur. Bu dönemde, özellikle, suyu artan nüfusa yetebilecek daha verimli bölgeler, arazinin artan nüfusa yetecek nitelik ve genişlikte olması, diğer yerleşmelerle bağlantının rahat sağlanması ve askeri-stratejik bakımdan korunaklı noktaların tercih sebebi olduğu görülmektedir ${ }^{24}$. Bu yüzden, OTÇ/STÇ yerleşmelerinin debisi çok yüksek su kaynakları, verimli tarım arazileri ve korunaklı tepecikler ya da tepeler üzerinde kurulduğu gözlenir $^{25}$.

${ }^{22}$ Koçak 1993, 19; Işın vd. 1992, 4, harita; Burney 1956, 184. Kocagòz Hōyüğü'nün Troia III ve Yortan kültürleriyle (IT.I) paralel olduğu görülür. Bunun yanında, kendine has bazı kültürel özelliklerinin olması Orta ve Bat Anadolu'ya karşı oldukça kapalı bir bölgede bulunmasından dolayıdır. Bkz. Işın 1991, 177; French 1988, 10; Erzen 1956, 6.

${ }^{23}$ Erzen 1956, 5 vdd.; Işıı vd. 1992, 4, harita.; Işın 1998, 249 vdd.; Işıı 1991, 177; Orthmann 1963, 49, 52, Tafel 96, 98-2; Koçak 1993, 17 vdd.

${ }^{24}$ Samsun-Bafra kesiminde yer alan İkiztepe'nin ITÇ ve OTÇ'daki yerleşim durumu, bunun açık bir kanıtıdır. Bkz. Bilgi 1999 a, 41 vdd.; Bilgi 1998, 63 vdd.

${ }^{25}$ Nitekim, Anadolu'daki önemli OTÇ/STÇ yerleşmelerinin kayalık alanlar üzerine kurulduğu görülmektedir. Orta Karadeniz Bölgesi'nde bu dönemi veren en önemli yerleşmelerden Maşat Höyüğŭn, kalker bloklar üzerine oturduğu görülür. Bu tür yerleşmelerin kurulduğu kayalık alanlar, etraftaki araziden yüksek olduğundan tahkimatun yanı sıra, engebeli doğa da savunmada yardımcıdır. Bu durum, Orta Anadolu'daki önemli yerleşmelerden Boğazkōy'de de böyledir. Ayrıca Maşat Höyük, büyük bir şehrin oluşması için gerekli bütün olanaklara sahiptir. Yapı malzemesi için gerekli taş ve ağaç kolayca sağlanabilmektedir. Bunun yanında, bu yerleşme Kuzey-Güney yoluna da hâkim bir konumda yer alır. Bu konularda ayrıntulı bilgi için bkz. T. Özgüç, Maşat Höyük Kazıları ve Cevresindeki Araşurmalar, Ankara, 1978, 2; T. Özgūç, Maşat Höyük II, Boğazkōy'ün Kuzeydoğusunda Bir Hitit Merkezi, Ankara, 1982, 1 vdd.; A. M. Dinçol, "Hititler" Anadolu Uygarlıkları, Görsel Anadolu Tarihi Ansiklopedisi, I (1982), 18-120, 1, 66 vd.; M. Darga, Hitit Mimarlı̆̆ı/ 1. Yapı Sanau, İstanbul, 1985, 30. Orta Karadeniz Bölgesi'nde bu dönem yerleşmeleri ile ilgili olarak bkz. Bilgi 1998, 63 vdd. 
Yukarıda, yerleşmelerin kurulmasında savunmanın önemli bir yer tuttuğundan sözetmiştik. Asayişin bozuk olduğu ve istila tehlikesinin hüküm sürdüğü devirlerde ve yerlerde, özellikle yüksek mevkilerin tercih edildiği görülür. Ancak, bu yüksek mevkiler, ticari bakımdan elverişli olmamasından dolayı, sadece savunma amaçh olarak ve asayişin bozuk olduğu dönemlerde önem kazanır ${ }^{26}$.

Orta Karadeniz Bölgesi'ndeki, Phryg ya da Demirçağı yerleşmelerinin de, yerleşim modellerinin bu yönde değiştiği görülür. Bunlar, özellikle, doğal bakımdan korunaklı, dağlık kesimlere doğru yönelmişlerdir. Bu durum da, sözü edilen dönemde duyulan savunma ve korunma ihtiyacıyla ilgili olmalıdır ${ }^{27}$.

Demir Çağı'nda Orta Karadeniz Bölümü'nde yerleşmelerin kentleşme özelliklerinin fazla olmadığı anlaşılmaktadır ${ }^{28}$. Ancak, bu bölgedeki kıyı yerleşmeleri, ekonomik faaliyetlerinden dolayı biraz daha iyi durumdadır.

Yine, başta Sinope olmak üzere, bu bölgedeki Grek koloni yerleşmelerinin, ana kentlerin bazı özelliklerini taşıdıkları görülmektedir. Nitekim, Sinope bir yarımada kıstasında kurulması ve çift limanı ile bunun kanıtıdır (Levha II-III; Plan). Ancak bu yerleşmelerin, kapladıkları alan ve mimari özellikler bakımından, Batı Anadolu kentlerinden çok geri oldukları görülmektedir ${ }^{29}$.

Bölgedeki kıyı yerleşmeleri, topoğrafyaları bakımdan üç grupta incelenmektedir. Bunlardan bir grup da: Yarımada, kıyıya birleşmiş ada, dil ya da burun üzerine kurulmuş şehirlerdir. Savunması kolay olan bu, tipik denizaşırı yerleşmelere Sinope güzel bir örnektir (Levha II-III; PLAN). Nitekim, A. Akarca, Sinope kentini burun tarafı dağlık bir yarımadanın boynu üzerine kurulmuş yerleşmeler arasında saymaktadır ${ }^{30}$.

${ }^{26}$ S. Gōney, Şehir Coğrafyası I, İstanbul, 1984 232.

${ }^{27}$ Bu yerleşmelerle ilgili olarak bkz. Kōkten vd. 1945, 396 vd.

${ }^{28}$ V.Sevin, "Eski Anadolu Halkları: Mozayiğe Genel Bir Bakış", Palmet, II (1998), 21-35, 30 vd.

${ }^{29}$ Bölgedeki önemli ana şehirlerden birisi olan Miletos için bkz. Wycherley 1986, 16, 56 vdd. Karadeniz kuy yerleşmelerinin Yunan kentleri ile benzerliği, denizaşın göçlerle ilgilidir. Sinope de, yerleşim özellikleri ve kent planı bakımından ana şehri Miletos'a benzemektedir. Bu konuda bkz. Akarca 1987, 24 vdd., resim 7.

${ }^{30}$ Bkz. Akarca 1987, 26. 
Sinope, Bozburun yarımadasının boynu üzerine kurulmuştur. Bu yarımada, çepeçevre dik kıyılarla çevrilidir ${ }^{31}$. Burası, bölgedeki en önemli liman kentlerindendir. Burada, iki liman bulunmaktadır. Bu limanlardan, batida yer alanı, kuzeybatıdan esen sert rüzgarlara açık olduğundan daha az kullanışlıdır. Doğu limanı ise, kış fırtınalarında bile gemilere güvenli bir korunma imkanı sağlamaktaydı (Levha II-III; Plan: 2-3) ${ }^{32}$.

Buradaki, Hamsilos (Hamsaros) Burnu, kuzeydoğu yönüne doğru, Akliman'ın kuzey tarafına yakın sahilden, kısa bir çıkıntı teşkil eder ve kayalık kıyıdan yanım mil uzağa kadar uzanır. Biraz ileride, tepe ve kayalıkların kenarında bulunan alçak kumsalın kuzeybat sınırında ise Akliman (Harmene: Akliman ) yeralır. Bu liman, Sarıada ve Karaada isimli iki ada tarafindan korunmaktadır. Bunlardan, Karaada kuzey başlangıç noktasına, Sarıada ise güney başlangıç noktasına yakındır. Batıda yer alan İnceburun Yarımadası, Akliman kesimine doğru, kuzey rüzgarlarının neden olduğu etkili dalgaları önlemektedir ${ }^{33}$.

Sinope, Yunan kolonizasyonu sırasında önemli bir rol oynamıştır. Kentin en önemli özellikleri: liman olarak konumu, Kuzey Anadolu'nun en uç noktasında bulunması ve Orta Anadolu'yla olan bağlantısıdır. Ancak, Sinope gücünü, kara bağlantularından daha çok denize borçludur. Ayrıca, bu kent, açık havalarda Kırım ile yapılan deniz seferlerinden dolayı, uzun zaman önemini korumuştur. Kent, konumundan dolayı Akdeniz ticaretinde önemli bir yer kazanmıştır ${ }^{34}$.

Sinope'nin bir diğer önemli özelliği, çok iyi bir şekilde tahkim edilmiş olmasıdır. Kentin, Pontos Kralı II. Mithradates'in yaptığı (M. Ö. 220) saldırıya ve Roma kuşatmasına karşı direnmesi bu tahkimatlı yapıyla ilişkilidir. Sinope'yi, ana karaya bağlayan dar boğaz, büyük duvarlar tarafindan korunmaktaydı. Denizden yapılacak saldırılar da, yarımadayı çevreleyen dik kayalardan dolayı imkansizd1 ${ }^{35}$.

${ }^{31}$ Sinop'da mezarlıkta ve yarımada boynu üzerinde yapılan kazı çalışmalarında M. Ö. 7 . yüzyıl sonlarına kadar giden buluntular ele geçmiştir. Bkz. Akurgal 1956, 47 vdd.; AkurgalBudde 1956, 4 vdd.; Boysal 1958, 23 vdd.

${ }^{32}$ Polybios, Historiai, IV.56; Strabon, Geographika, XII.3.11. Ayrica bkz. Akarca 1987, 26, 36 vd., resim 7; Stoop 1978, 118 vdd.

${ }^{33}$ Strabon, Geographika, XII.3.10-11; Ksenophon, Anabasis, VI.1.15-17; Ksenophon, Hellenika, VI. 1.11-17; Plinius, Naturalis Historia, VI.2. Aynca bkz. Stoop 1978, 118 vdd.

${ }^{34}$ Leaf 1916, 3. Ayrica bkz. Boysal 1958, 27.

${ }^{35}$ Polybios, Historiai, IV.56; Strabon, Geographika, XII.3.11; Plinius, Naturalis Historia, v1.2, 6-7. 
Yerleşimle ilgili bir diğer belirleyicinin, tarihi doğal yollar olduğu bilinmektedir. Sinop da, önemli tarihi doğal yollar üzerinde yer almaktadır. Sinop'un başlangıç noktası olduğu önemli tarihi doğal yol güzergahı, buradan Akdeniz kıyılarına kadar uzanan Kuzey-Güney Yolu'dur ${ }^{36}$.

Yukarıda bu yol bağlantılarının, yerleşme yerlerinin seçiminde de önemli rol oynadığından sözetmiştik. Nitekim, Sinop'daki bazı yerleşmelerin batıda Ayancık, doğuda Gerze ile bağlantının sağlandığı yollar üzerinde kurulduğu görülür. Sinop-Gerze arasındaki bağlantı, buradan Samsun'a uzanan tarihi doğal yolun bir kısmını teşkil etmektedir (Harita 2) ${ }^{37}$.

Sinop'un hinterlandla ilişkisini sağlayan en önemli bağlantılarından birisi Boyabat'a kadar uzanan yoldur ${ }^{38}$. Burasi, muhtemelen Sinop'u güneye doğru inen bir yol ile Amnias (Gökırmak) Ovası'ndan Doğu-batu yoluna bağlayan tarihi yoldur ${ }^{39}$. İncelediğimiz yerleşmeler içerisinde de Sinop-Boyabat

${ }^{36}$ W. M. Ramsay, "Some Phrygian Monuments", JHS, III (1882), 256-263, 260; J. A. R. Munro, "Roads in Pontus, Royal and Roman", JHS, XXI (1901), 52-66., 52 vdd.; Leaf 1916, 3; Burney 1956, 179 vd.; W. M. Calder- G. E. Bean, A Classical Map of Asia Minor, London, 1958, harita; W. M. Ramsay, Anadolu'nun Tarihi Coğrafyası, Çev. M. Pektaş, İstanbul, 1960, 27 vd.

${ }^{37}$ Leaf 1916, 3 vd.; Burney 1956, 182; B. Darkot, "Sinop", İslam Ansiklopedisi, X (1988). 683-689, 684. Kastamonu-Taşkōprü-Sinop üzerinden, Samsun'a uzanan bir yolun varlığı bilinmektedir. Bu yolun, Sinop'dan Samsun'a uzanan belli bir kesimi belirlenmiștir. Yol, Sinop'dan sonra Gerze'ye (Karousa), oradan da Samsun sınırında bulunan Çayağzı'na ulaşmaktadır. Bkz. D. H. French, "Roma Yolları ve Miltaşları: 1984", AST, III (1986), 143-154, 145; D. H. French, "Roman Roads and Milestones of Asia Minor 1989", AS, The Years Work, XL (1990), 9-11, 9; D. H. French, "1989 Roma Yolları Miltaşları ve Yazıtları Araşturması", AST, VIII (1991), 229-240, 229.

${ }^{38}$ D. R. Wilson, The Historical Geography of Bithynia, Paphlagonia and Pontus in the Greek and Roman Periods, a New Survey with Particular Reference to Surface Remains Still Visible (Yayınlanmamış Doktora Tezi), Oxford, 1960, 180. Sinop'dan başlayarak, güneyde Boyabat, oradan da İskilip'in alunda Kızılırmağa ve nehri geçtikten sonra Alaca Ovası, Sorgun ve Sarıkaya'ya doğru devam eden ve "Ceneviz Yolu" olarak isimlendirilen bir yol vardır. Bkz. D. H. French, "Sinop: the So-Called Ceneviz Yolu", Tahsin Özgüç'e Armağan/Studies in Honor of Tahsin Özgüç, Anatolia and the Ancient Near East, ed. K. Emre-B. Hrouda- M. Mellink- T. Özgüç, Ankara, 1989, 143-147, PI.35-36, 143.

${ }^{39} \mathrm{H}$. Weimert, Wirtschaft Als Landschaftsgebundenes Phänomen. Die Antike Landschaft Pontos. Eine Fallstudie, (Doktora Tezi) Stuttgart, 1983, 184 vd. Bu yol güzergahı, güneydeki doğu-batu yollarından birisiyle bağlanır. Bu doğu-bat yolu Daday'ın doğusundan Taşköprü'ye (Pompeiopolis: Zımbıllı Tepe), buradan da Gōkırmak Vadisi boyunca devam ederek Boyabat'a ulaşır. Gökırmağın Kızılırmak ile birleștiği yerden Vezirköprü'ye (Neoklaudiopolis) inen yol, buradan Niksar'a kadar gider. Bkz. Burney 1956, 181 vd.; D. H. French, "CIL XVII Fasc. 5. Roman Roads and Milestones of Asia Minor; Recam: Sinop", AS, The Year's Work, XXXIII (1983), 9-10, 10; D. H. French, "Roman Roads and Milestones in Anatolia 1982", AST, I (1984). $87-88,88$; D. H. French, "Roads and Milestones 1984 ", AS, The Year's Work, XXXV (1985), 8- 
arasındaki yol bağlantısı belli kesimlerde açık bir şekilde gözlenebilmektedir (Harita 2).

Yukanda da sözettiğimiz gibi, coğrafi yapı özelliklerinden dolayı Sinop' un yol bağlantularının çok güçlü olmadığı görülmektedir. Bu yüzden, Sinop' un dış dünyayla deniz yolu ile olan bağlantısı da gözardı edilmemelidir ${ }^{40}$. Nitekim, Güney Karadeniz kıylarındaki en önemli limanın bu kesimde bulunduğu görülmektedir. Burada, iki liman bulunmaktadır. Bunlardan, baudaki, kuzeybatıdan esen sert rüzgarlara açık olduğundan daha az kullanışlıdır. Ancak, doğu limanı kış fırtınalarında bile gemilere güvenli bir korunma imkânı sağlamaktaydı. Sinope, çift limanıyla, Hellen dünyasında görülen kentleri andırmaktadır ${ }^{41}$.

\section{Yerleşmelerdeki Kültürler ${ }^{*}$}

Sinop'daki yerleşim durumuyla ilgili olarak toplam 53 yerleşmeyi esas aldık. Bunlar arasından da Kalkolitik Çağ'dan Hellenistik Dönem'e kadar olan kültürleri içinde barındıran 50 yerleşme esas alındı (TABLO 1-6; Harita 2: 1-4) ${ }^{42}$. Ayrıca, OTÇ ile STÇ, sözedilen dönemlerdeki siyasal ve sosyal karı-

10, 9; D. H. French, AST, III (1986), 145; D. H. French, "Roman Roads and Milestones of Asia Minor", AS, The Years Work, XXXVII (1987), 8-11, 10; French 1988, 9; D. H. French, Roman Roads and Milestones of Asia Minor 1-2, Ankara, 1988, Map 12; D. H. French, "1987 Yilı Roma Yollan ve Miltaşlan Çalışması", AST, VI (1989), 273-281, 275.

40 D. M. Robinson, "Ancient Sinope", American Journal of Philology, XXVII/2 (1905). 125-153, 135 vd.; J. A. R. Munro, JHS, XXI (1901), 53 vdd.; Leaf 1916, 3. Örneğin; gemicilikteki ilerlemeler sonrası, M.Ö. 5. yüzyıl sonu ve M.Ö. 4. yüzyıl başlarında kısa bir deniz rotası bulunmuştur. Bu rota, Kırım'daki Kriou Metopon (Sariç Burnu) ve Sinop'un 130 km. kadar bausındaki Karambis (Kerempe Burnu) arasındaki 140 mil uzunluğundaki deniz yoludur. Bu rota, deniz ticaretinin gelişmesi açısından çok yararlı olmuştur. Bkz. Ps. Skymnos, 593. Ayrıntulı bilgi için bkz. S. Atasoy, Amisos, Karadeniz Kıyssında Antik Bir Kent, Samsun, 1997, 80, dipnot 69.

${ }^{41}$ B. C. Mc Ging. The Foreign Policy of Mithridates VI Eupator, King of Pontus, Leiden, 1986, 3; E. Olshausen, Einführung in die Historische Geographie der Alten Welt, Darmstadt, $1991,174$.

* Burada değerlendirmelerimiz, Sinop'da yapılan bilimsel yüzey araşurmaları ve kazı esas alınarak yapılmıştur. Bu konuda örnek bir çalışma için bkz. T. Ökse, "Yukarı Kızılırmak Havzası Tunç Çağları ve Demirçağ Yerleşim Tarihi”, Belleten, LXII-234, 1998 (1999), 299-336. Ayrıca bkz. Koçak 2000, 48 vdd.

42 İnceburun'daki Üst Paleolitik (M. Ö. 40000-12000) döneme ait olduğu iddia edilen (Bkz. Işın vd. 1992, 4, harita; Işın 1998, pl. 1) bir merkez dışında Sinop kesiminde Kalkolitik Çă̆ ōncesini veren buluntulara rastlanmamıştır. Samsun Bölgesi'ndeki araşturmalar bu bölgenin ilk defa Geç Kalkolitik Çağ'da iskan edilmeye başlandığını gösterir. Bkz. Bilgi 1990, 1. 
şılıklar ve bazı problemlerden dolayı birlikte ele alınarak değerlendirildi ${ }^{t^{3}}$. Yine, Hellenistik Dönem ve sonrası da yerleşim durumuyla ilgili verilerden dolayı harita ve grafiklerde verilmemiştir.

\section{TABLO 1}

\begin{tabular}{|l|c|c|c|c|}
\hline & Kalkolitik & İTC & OTÇ/STC & DC \\
\hline SiNOP & 15 & 47 & 13 & 7 \\
\hline$\%$ & 18,2 & 57,3 & 15,8 & 8,5 \\
\hline
\end{tabular}

Sinop'un bu erken yerleşmelerinde en yaygın kültür İTÇ'a ait olanıdır. Buradaki İTÇ kültürleri bütün höyükler içinde $\% 57,3^{\prime}$ lük bir oranda ( 47 tane) yer almaktadır (Tablo 1, 3-6; Harita: 1-2). Bu, Sinop yerleşmelerindeki en yaygın kültürün İTÇ’a ait olduğunu açıkça göstermektedir. Bunu, \% 18,2' lik oranla Kalkolitik (15 adet), \% 15,8 ile OTÇ/STÇ (13 adet) ve \% 8,5 ile DÇ (7 adet) yerleşmeleri takip eder (Tablo 1, 3-6; Harita: 1-2).

Kalkolitik Çağ'dan İTÇ’a geçişte yerleşmelerin sayısının yaklaşık 3 kat artması, nüfustaki artı̧ı göstermektedir. Ancak, bu dönem yerleşmelerinin genelde küçük ve orta boy höyükler olduğu da gözardı edilmemelidir.

Genel olarak, Anadolu'da olduğu gibi ${ }^{44}$ Sinop'da da ITCÇ'dan OTÇ/STÇ'a geçişte yerleşmelerin sayı olarak azaldığı görülmektedir. Sinop'ta İTÇ'dan OTÇ/STÇ'a geçişte, yerleşmelerinin sayısının yaklaşık $1 / 4$ oranında azaldığı görülür (Tablo 1, 3-6; Harita 2). Bu durum muhtemelen OTÇ/STÇ içindeki sosyal ve siyasal değişim ve gelişmelerle ilgili olmalıdır. Nitekim, genel olarak ITÇ sonları ve OTÇ başlarında Anadolu'da başlayan ekonomik ve ticari değişim ve gelişim muhtemelen bu yerleşmelerde de kendini göstermiş, tarihi doğal yollar üzerindeki yerleşmeler daha da önem kazanmışlardır. Bunun yanında siyasal problemler ve küçük krallıkların (ya da kent devletleri) kurulmasıyla ilk siyasal yapılanmalar da ortaya çıkmaya başlamıştur. Bu siyasal ve ticari değişim, insanların küçük köyleri terkederek,

43 Ö. Bilgi, İkiztepe ve Dündartepe'nin, Orta Anadolu'daki Acemhöyük ve KonyaKarahöyük gibi M.Ö. 18. yüzyılda terkedildiğini bildirerek bu yerleşmelerde Eski Hitit ve Hitit İmparatorluk Çağı kültürlerinin bulunmadığını ileri sürer. Bu durumu da, Kaşkaların bu kesimde egemenlik kurmalarıyla ilişkili görür. Bkz. Bilgi 1998, 66.

${ }^{44}$ Burney 1956,$82 ; 183$ vd. 
sözettiğimiz merkezi-büyük yerleşmelere yönelmelerine neden olmuş olmalidir ${ }^{45}$.

Bölgenin, özellikle kuzey kesimlerindeki M.Ö. II. bin yl yerleşmelerinin çoğunun, Hitit İmparatorluk Çağı kültürlerini vermemesi ise, bölgedeki Kaşka egemenliği ve Kaşka saldırıları ile ilgili olmalıdır (Tablo 3-6) ${ }^{46}$.

Sinop kesiminde bilinen DÇ yerleşmelerinin de sayı olarak çok az olduğu görülür (Tablo 1, 3-6; Harita: 1-2). Bu durum, Anadolu'da bu dönemde görülen karışıklıklarla ilgili olmalıdır. Muhtemelen DÇ halkları, kendilerini bu karışıklıktan koruyacak, dağlık veya daha korunaklı bölgelere yönelmiş olmalıdır.

Bölge yerleşmeleriyle ilgili olarak değerlendirme yaparken ele aldığımız ikinci bir husus ta, kültürlerdeki süreklilik idi.

Sinop'ta ele aldığımız 53 yerleşme içinde yaklaşık 82 kültürün bulunduğu görülmektedir (Kalkolitik'ten Hellenistik Dönem başına kadar) (TABLO 2, 3-6; Harita: 3-4).

Bunlar arasında, İTÇ kültürleri, bir höyükte tek başına en yüksek oranda bulunan kültür durumundadır. Bunun oranı \% 44'dür (22 adet).

45 Bilgi 1999 a, 44. Kastamonu yerleşmelerinde de ITC III sonlarından itibaren yerleşmelerin kapladığı alanların genişlediği hakkında bkz. Özdoğan vd. 2000, 47. Bu yerleşmelere örnek olarak İkiztepe için bkz. Alkım vd. 1988, 1 vdd.

${ }^{46}$ Kaşkalar'ın yaşamış olduklan yerler, Hitit Devleti'nin kuzeyinde kabaca Sinop ve Ordu arasındaki bōlgedir. Ancak, Hitit hâkimiyetinin zayfladığı dönemlerde bazen Pala-Tum(m)ana gibi çevre bölgelerde de egemenlik kurmuşlardır. Diğer bir deyişle, Kaşkalar Pala, Tum(m)ana ve Azzi-Hayaşa ile komşudurlar. Bkz. A. Ünal, "Orta ve Kuzey Anadolu'nun M.Ö.2. Binyl İskan Tarihiyle İlgili Sorunlar”, Anadolu/ Anatolia, ed. C. Bayburtluoğlu, XXII, 1981/1983 (1989). 17-37, 26; H. Ertem, Hitit Devleti'nin Iki Eyaleti: Pala-Tum(m)ana, Ankara, 1980, 7 vdd.; J. Garstang- O. R. Gurney, The Geography of the Hittite Empire, London, 1959, harita; E. Von Schuler, Die Kaşkaer, Berlin, 1965, 12 vdd.; T. Bryce. "The Boundaries of Hatti and Hittite Border Policy". Tel-Aviv, 13-14 (1986), 85-102, 85; J. Yakar, "Anatolian Civilization Following the Disintegration of the Hittite Empire: An Archaeological Appraisal", Tel-Aviv, XX-1 (1993), 3-28. 5, fig. 1; G. F. Del Monte-J. Tischler, Répertoire Géographique des Textes Cunéiformes, VI, Die Orts- und Gewässernamen der Hethitischen Texte Supplement, Wiesbaden, 1978, 190 vdd., 297 vd., 437 vd.; G. F. Del Monte, Répertoire Géographique des Textes Cunéiformes, VI/2, Die Orts- und Gewässernamen der Hethitischen Texte Supplement, Wiesbaden, 1992, 72 vd., 118 , 173. A. Dinçol-J. Yakar da, Kaşka Ülkesinin, Amasya-Merzifon hatunın kuzeyinde ve Sinop-Ordu arasında yer aldığını düşünmektedirler. Bkz. J. Yakar- A. M. Dinçol, "Remarks on the Historical Gegraphy of North-Central Anatolia During the Pre-Hittite Periods". Tel Aviv, I (1974) , 85-99, 86 vdd., 564; Koçak 2000, 57. 
Bunun yanında, höyüklerde Kalkolitik ve İTÇ yerleşmelerinin birarada bulunma oranları da \% 28 idi (14 adet). Buradaki 15 Kalkolitik kültürden 14 'ünün üzerinde İTÇ'in devam etmesi (\% 93,3), Kalkolitik'ten İTÇ’a geçişteki sürekliliği göstermektedir (Tablo 2, 3-6; Harita: 3-4) ${ }^{47}$.

Ayrıca değerlendirmeye aldığımız yerleşmelerden üçü dışındaki diğer bütün merkezlerde İTÇ kültürlerine rastlandığı görülmektedir.

Sinop yerleşmelerinde süreklilik gösteren ikinci kültür grubu: İTÇ ile OTÇ/STÇ kültürleridir. Bunlar da, toplam içinde \% 26'lık bir orana (13 adet) sahiptir (Tablo 2, 3-6; Harita: 3-4).

Bu yerleşmeler arasındaki bütün OTÇ/STÇ kültürlerinin, İTÇ kültürleri üzerinde kurulduğu görülür (13 adet; Tablo 2, 3-5; Harita: 3-6).

DÇ yerleşmelerinin de $3 / 4$ ' lük bir oranı İTÇ kültürleriyle birlikte yer almaktadır (Tablo 2, 3-6; Harita: 3-4).

\section{TABLO 2}

\begin{tabular}{|c|c|c|c|c|c|c|c|c|c|}
\hline & Kalkolitik & trc & DC & $\begin{array}{l}\text { Kalkolitik- } \\
\text { IrC }\end{array}$ & $\begin{array}{l}\text { Kalkolitik- } \\
\text { ITC } \\
\text { OTÇ/STC }\end{array}$ & $\begin{array}{l}\text { trC. } \\
\text { OTC/ } \\
\text { STC }\end{array}$ & trc $-D C$ & $\begin{array}{l}\text { trC- OTC/ } \\
\text { STC-DC }\end{array}$ & TOPLAM \\
\hline SLNOP & 1 & 22 & 2 & 10 & 4 & 6 & 2 & 3 & 50 \\
\hline$\%$ & 2 & 44 & 4 & 20 & 8 & 12 & 4 & 6 & 100 \\
\hline
\end{tabular}

Karadeniz Ticari Projesiyle ilgili çalışmaları değerlendiren Amerikalı bir ekip, Sinop İTÇ yerleşimlerinin yoğunluğunun daha sonraki dönemlerde azaldığını bildirir. Hellenistik Dönemde ise, iç kesimlerde az olmakla beraber, kıyı şeridindeki yerleşimlerde önemli bir gelişmenin varlığı saptanmışur. Roma ve Erken Bizans dönemlerinde o zamana kadar görülmeyen bir gelişme gözlenmektedir. Bu dönemlerde, iç kesimlerde de nispi bir gelişme olmuştur. İç kesimlerdeki gelişmeyi, kıyıdaki gelişmeyle ilgili görmek gerekmektedir. Çünkü, iç bölgeler, kıyıdaki hammadde ihtiyacını desteklemekte-

${ }^{47}$ Nitekim, Kastamonu kesimindeki Kalkolitik ve İTÇ I-II yerleşmelerinin de genellikle üst üste bulunduğu ve bu yerleşmelerin küçük bir alan kapladıkları anlaşılmışur. Bkz. Özdoğan vd. $2000,46 \mathrm{vd}$. 
$\operatorname{dir}^{48}$. Demirci Vadisi ve Sinop çevresi Hellenistik-Roma yerleşmelerinin yoğunluğu da siyasal, sosyal ve ekonomik değişim ve gelişmelerle ilgili bir durumdur $^{49}$. Nitekim, Sinop'un bausindaki Bafra Ovası'nda da Hellenistik Dönem boyunca yaygın olarak yerleşilmiştir ${ }^{50}$.

Burada dikkat çekici bir diğer konu da, saydığımız kültürlerin bütününün hemen hiçbir yerleşmede bir arada görülmemesi; ya da bu yerleşmelerdeki kültürel sürekliliğin çok az olmasıdır (Tablo 2, 3-6).

Bütün bunlardan, yerleşim şekillerinin oluşmasında insan iradesinin ve coğrafi özelliklerin belirleyicilikleri ortaya çıkmaktur. İnsanlar, yerleşim yerlerini seçerken tesadüflerle hareket etmemişlerdir. Su kaynakları, verimli tarım arazileri, doğal yol güzergahları, nehir vadileri, maden yatakları vb. bu seçimde etkili olmuştur ${ }^{51}$. Siyasal, askeri ve ekonomik yapı özellikleri ve değişimler de bu tercihlerde belirleyici olmuştur. Sinop yerleşmelerinde de, söylediğimiz bu tercih sebepleri aranmıştur. Harita üzerine yapuğımız yerleştirmede bütün bu unsurların önemi açık şekilde görülmektedir (Harita 2).

48 Doonan vd. 1998, 367; Doonan vd. 1999, 367; I. Tatlıcan, “Sinop, Çiftlik Köyü, Mozaik Kurtarma Kazısı", Müze Kurtarma Kazılan Semineri, VII (1997), 333-356, 341; Hiebert 1997. 377; Koçak 2000, 147 vdd.

49 Doonan vd. 1998, 367; Doonan vd. 1999, 364 vdd.; E. S. G. Robinson, “A Find of Coins of Sinope". Numismatic Chronicle, XX (1920), 1-16, 1 vdd.

${ }^{50}$ Bilgi 1999 b, 38.

${ }^{51}$ Sinop'un doğusunda Bafra'da yer alan İkiztepe, bu bōlgede, sōzünü ettiğimiz yerleşim tercihi ile ilgili güzel bir örnektir. Bkz. Alkım vd. 1988, 5 vdd.; Bilgi 1990, 2; Bilgi 1994, 253 vdd.; Bilgi 1999 a, 43 vd. Ayrıca, Kastamonu-Kınık yerleşmesi ile ilgili olarak bkz. Çınaroğlu 1991, 55 vdd.; Emre-Çınaroğlu 1993, 675; Bilgen 1999, 269 vdd. Durağan kesimindeki maden kaynakları hakkında bkz. Özbal vd. 2000, 48 vd. 
TABLO $3^{\circ}$

\begin{tabular}{|c|c|c|c|c|c|c|c|c|}
\hline \multirow[t]{2}{*}{ NO } & \multirow[t]{2}{*}{ tsim } & \multirow[t]{2}{*}{$\begin{array}{l}\text { ПL/ ILCEE } \\
\text { KŐY }\end{array}$} & \multirow{2}{*}{ 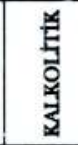 } & \multicolumn{2}{|c|}{ TUNÇ CAĂ̆I } & \multirow[t]{2}{*}{ Demir } & \multirow{2}{*}{ 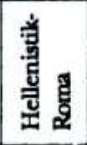 } & \multirow{2}{*}{ GÖNDERME } \\
\hline & & & & Inc & OTÇstc & & & \\
\hline 01 & Sinop & Sinop-Merkez & & & & $\mathrm{x}$ & $\mathrm{x}$ & $\begin{array}{l}\text { Akurgal } 1956,47 \text { vdd;; } \\
\text { Akurgal-Budde 1956, } 4 \text { vdd; } \\
\text { Erzen 1956, } 3 \text { vdd. }\end{array}$ \\
\hline 02 & Kılıçı Tepe & $\begin{array}{l}\text { Sinop-Merkez } \\
\text { Kulıçlı }\end{array}$ & GKÇ & $\mathrm{x}$ & OTC & & & $\begin{array}{l}\text { Işın 1990, 247; Işıı vd. 1992, } \\
\text { 4; Dönmez 2000, 229; Işın } \\
\text { 1998,99. }\end{array}$ \\
\hline 03 & $\begin{array}{l}\text { Maltepe } \\
\text { (Hacioğlu) }\end{array}$ & \begin{tabular}{|l|} 
Sinop-Merkez \\
Hacioğlu
\end{tabular} & GKC & $\mathrm{x}$ & & & & $\begin{array}{l}\text { Isın 1990, 248; Burney } 1956 \text {, } \\
181 ; \text { Işn vd. 1992, } 4 \text {; Işın } \\
1998,99 \text {; Doonan vd. } 2000 \text {, } \\
346 \text { vd. }\end{array}$ \\
\hline 04 & Kocagöz $\mathrm{H}$. & \begin{tabular}{|l|} 
Sinop-Merkez \\
Demirci
\end{tabular} & $\mathrm{x}$ & $\mathrm{x}$ & & & & $\begin{array}{l}\text { Issin 1990, 248-249; Burney } \\
1956,181 ; \text { Issın vd. 1992, 4; } \\
\text { Isin 1998, 99; Orthmann } \\
1963,49 .\end{array}$ \\
\hline 05 & Habuhas Tepe & $\begin{array}{l}\text { Sinop-Merkez } \\
\text { Bektaşağa }\end{array}$ & & $\mathrm{x}$ & & & & $\begin{array}{l}\text { Issın 1990, 249; Ișin vd. 1992, } \\
4 \text {; Isın 1998, 101. }\end{array}$ \\
\hline 06 & Mezarlık Tepe & $\begin{array}{l}\text { Sinop-Merkez } \\
\text { Yalı }\end{array}$ & $\mathrm{x}$ & $\mathrm{x}$ & & & & $\begin{array}{l}\text { Issin } 1990,253 \text {; Işın vd. 1992, } \\
4 ; \text { Ișin } 1998,99 .\end{array}$ \\
\hline 07 & Ilya'nun Yeri & $\begin{array}{l}\text { Sinop-Merkez } \\
\text { Lala Alunoğlu }\end{array}$ & $\mathrm{x}$ & $\mathrm{x}$ & & & & $\begin{array}{l}\text { Issin 1990, 253-254; Işin vd. } \\
1992,4 \text {; Ișin 1998, } 99 \text { vd. }\end{array}$ \\
\hline 08 & $\begin{array}{l}\text { CCimbek Tepe } \\
\text { (LEVHA l: 1) }\end{array}$ & $\begin{array}{l}\text { Sinop-Merkez } \\
\text { Lala Tavikçu- } \\
\text { luğuı }\end{array}$ & $\mathrm{x}$ & $\mathrm{x}$ & & & & $\begin{array}{l}\text { Issın 1990, 254; Ișin vd. } 1992, \\
4 ; \text { Işın 1998, 100; Doonan } \\
\text { vd. 2000, 346. }\end{array}$ \\
\hline 09 & Tingıroğlu & \begin{tabular}{|l|} 
Sinop-Merkez \\
Tingıroğlu
\end{tabular} & & $\mathrm{x}$ & OTC & $\begin{array}{l}\text { Phryg } \\
\text { GDC }\end{array}$ & Roma & $\begin{array}{l}\text { Işın 1990, 255; Ișin vd. } 1992 \text {, } \\
4 ; \text { Işı 1998, 103 vd.; } \\
\text { Dönmez. 2000,230. }\end{array}$ \\
\hline 10 & Maltepe & $\begin{array}{l}\text { Sinop-Merkez } \\
\text { Tepealu }\end{array}$ & & $\mathrm{x}$ & & & & $\begin{array}{l}\text { Işı 1990, 255; Işın vd. 1992, } \\
4 ; \text { Işın 1998, 104; Orthmann } \\
1963,52 .\end{array}$ \\
\hline 11 & Kabalı & $\begin{array}{l}\text { Sinop-Merkez } \\
\text { Kabalı }\end{array}$ & $\mathrm{x}$ & & & & & Işın 1998, 103. \\
\hline 12 & Yama Tepesi & $\begin{array}{l}\text { Sinop-Erfelek } \\
\text { Karaca }\end{array}$ & & $\mathrm{x}$ & & & & $\begin{array}{l}\text { Issin 1990, 245-246; Issin vd. } \\
\text { 1992, 4; Isin 1998, 97. }\end{array}$ \\
\hline 13 & Harman Tepe & $\begin{array}{l}\text { Sinop-Erfelek } \\
\text { Bıyklı }\end{array}$ & $\mathrm{x}$ & $\mathrm{x}$ & OTÇ? & & & $\begin{array}{l}\text { Issin 1990, 246; Isin vd. 1992, } \\
4 ; \text { Isin 1998, 97. }\end{array}$ \\
\hline 14 & Ciltepe & $\begin{array}{l}\text { Sinop-Erfelek } \\
\text { Basaran }\end{array}$ & & $\mathrm{x}$ & & & Roma & $\begin{array}{l}\text { Isin 1990, 246-247; Is sin vd. } \\
1992,4 ; \sin 1998,97 \text { vdd. }\end{array}$ \\
\hline 15 & Kumtepe & $\begin{array}{l}\text { Sinop-Erfelek } \\
\text { Hamidiye }\end{array}$ & & $\mathrm{x}$ & & & & $\begin{array}{l}\text { Issın } 1990,249-250 ; \text { Issıı vd. } \\
1992,4 \text {; Isin } 1998,101 .\end{array}$ \\
\hline 16 & Kahkül Tepe & $\begin{array}{l}\text { Sinop-Erfelek } \\
\text { Hamidiye }\end{array}$ & & $\mathrm{X}$ & & & & $\begin{array}{l}\text { Işın 1990, 250; Işın 1998, } \\
\text { 101 vd. }\end{array}$ \\
\hline 17 & $\begin{array}{l}\text { Halil Usta Te. } \\
\text { (LEVHA 1:2) }\end{array}$ & $\begin{array}{l}\text { Sinop-Erfelek } \\
\text { Hasandere }\end{array}$ & GKÇ & $\mathrm{x}$ & & & & $\begin{array}{l}\text { Issin 1990, 250-251; Issin vd. } \\
1992,4 ; \text { Isin 1998, } 102 .\end{array}$ \\
\hline 18 & Üvez Tepe & $\begin{array}{l}\text { Sinop-Erfelek } \\
\text { Kirenpara } \\
\text { mh. }\end{array}$ & & & & & & $\begin{array}{l}\text { Işın 1990, 251; Işıı vd. } 1992 . \\
\text { 4; Işıı 1998, 102. }\end{array}$ \\
\hline
\end{tabular}

* Burada, kesinliği anlaşılmayan ve yerleşim yerleri tam olarak bilinmeyen bazı merkezlerle; aynı zamanda yerleşim ōzellikleri taşımayan, nekropol ve bazı kaleler de verilmemiştir. Bunlar arasında, Sinop yakınlarındaki Gerze ve Tingiroğlu çevresiyle, bu kesimdeki diğer birkaç yerleşme saylabilir. Bkz. French 1988, 10. Ayrıca bkz. Doonan vd. 2000, 347 vd. Ayrica, Ínceburun'daki Üst Paleolitik (M. Ô. 40000-12000) bir merkez de burada verilmemektedir. Bkz. Işın vd. 1992, 4, harita; Işın 1998, pl. 1. Yerleşmelerle ilgili gōndermeler yaparken, bütün araşturmalar değil de, başlıca çalışmaların verilmesiyle yetinilmiştir. 


\section{TABLO 4}

\begin{tabular}{|c|c|c|c|c|c|c|c|c|}
\hline \multirow[t]{2}{*}{ NO } & \multirow[t]{2}{*}{ tsim } & \multirow[t]{2}{*}{$\begin{array}{l}\text { II. ILCE } \\
\text { KOY }\end{array}$} & \multirow{2}{*}{ 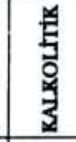 } & \multicolumn{2}{|c|}{ TUNÇ CAĞ } & \multirow[t]{2}{*}{$\begin{array}{c}\text { Demir } \\
\text { Cas }\end{array}$} & \multirow{2}{*}{ 总 } & \multirow{2}{*}{ GONDERME } \\
\hline & & & & Inc & OTGSSTC & & & \\
\hline 19 & Ören Tepe & \begin{tabular}{|l|} 
Sinop-Erfelek \\
Mecitdüzü
\end{tabular} & & $\mathrm{x}$ & & & Roma & $\begin{array}{l}\text { Işın 1990, 251-252; Işın } \\
\text { vd. 1992, 4; Işın 1998, } \\
102 .\end{array}$ \\
\hline 20 & Gavur Tepe & $\begin{array}{l}\text { Sinop-Erfelek } \\
\text { Kazma Sökü }\end{array}$ & & $\mathrm{x}$ & & $\begin{array}{l}\text { Phryg } \\
\text { GDC }\end{array}$ & Roma & $\begin{array}{l}\text { Işn 1990, 252; Işın vd. } \\
\text { 1992, 4; Işs 1998, } 102 \\
\text { vd.; Dönmez 2000,230. }\end{array}$ \\
\hline 21 & Sarumustafa Te pesi & $\begin{array}{l}\text { Sinop-Erfelek } \\
\text { Kazma Sökü }\end{array}$ & GKC & $\mathrm{x}$ & & & & $\begin{array}{l}\text { Issın 1990, 253; Işın vd. } \\
1992,4 ; \text { I } \sin 1998,103 .\end{array}$ \\
\hline 22 & Gölalu Tepesi & $\begin{array}{l}\text { Sinop-Erfelek } \\
\text { Gölalu }\end{array}$ & & & & & Roma & Dỏnmez 2000, 230. \\
\hline 23 & Cindilli Tepe & $\begin{array}{l}\text { Sinop-Erfelek } \\
\text { Dizdaroḡlu }\end{array}$ & $\mathrm{x}$ & $\mathrm{x}$ & & & & Işın 1998, 102. \\
\hline 24 & Tepecik Üstũ & $\begin{array}{l}\text { Sinop-Erfelek } \\
\text { Sorgun }\end{array}$ & & $\mathrm{x}$ & & & & Işın 1998, 103. \\
\hline 25 & Kuran Tepe & $\begin{array}{l}\text { Sinop-Erfelek } \\
\text { Cayrköy }\end{array}$ & & $\mathrm{x}$ & & & & Işın 1998, 103 \\
\hline 26 & Alma Cukuru & $\begin{array}{l}\text { Sinop-Gerze } \\
\text { Gözsökü }\end{array}$ & & $\mathrm{x}$ & & & $\begin{array}{l}\text { Hell- } \\
\text { Roma } \\
\end{array}$ & $\begin{array}{l}\text { Ișin 1990, 256; Işin vd. } \\
1992,4 ; \text { Isin 1998, } 104 \text {. }\end{array}$ \\
\hline 27 & Yanık Maltepe & $\begin{array}{l}\text { Sinop-Gerze } \\
\text { H dirlı }\end{array}$ & & $\mathrm{x}$ & & & & $\begin{array}{l}\text { Ișin 1990, 256; Issin vd. } \\
1992,4 ; 1 \sin 1998,104 \text {. }\end{array}$ \\
\hline 28 & Keçi Türbesi & $\begin{array}{l}\text { Sinop-Gerze } \\
\text { Hidurh }\end{array}$ & $\mathrm{x}$ & $\mathrm{x}$ & \begin{tabular}{|l|} 
OTC \\
bronz ok \\
uclan
\end{tabular} & & $\begin{array}{l}\text { Roma- } \\
\text { Gec } \\
\text { Roma }\end{array}$ & $\begin{array}{l}\text { Işın 1990, 256-257; Işın } \\
\text { vd. 1992, 4; Işın 1998, } 104 \\
\text { vd. Dönmez 2000. 230. }\end{array}$ \\
\hline 29 & Zeus Mabedi & $\begin{array}{l}\text { Sinop-Gerze } \\
\text { Sorgun }\end{array}$ & & & & & Hell. & $\begin{array}{l}\text { Işın 1990, 258; Işin vd. } \\
1992,4 ; \text { I } \sin 1998,109 .\end{array}$ \\
\hline 30 & Köşk Höyük & Sinop-Gerze & & $\mathrm{x}$ & Er Hitit & & & $\begin{array}{l}\text { Issın vd. 1992, 4, 7; Işın } \\
\text { 1998, } 100 \text { vd.; Dönmez } \\
\text { 2000,231. }\end{array}$ \\
\hline 31 & Kadı Mezan & $\begin{array}{l}\text { Sinop-Gerze } \\
\text { Sahinoğlu }\end{array}$ & & $\mathrm{x}$ & OTC ? & & & Işin 1998, $105 \mathrm{vd}$ \\
\hline 32 & Bakacak Tepe & Sinop-Gerze & & $\mathrm{X}$ ? & & & Hell. & Isin $1998,106$. \\
\hline 33 & $\begin{array}{l}\text { Maltepe Burum- } \\
\text { auk }\end{array}$ & $\begin{array}{l}\text { Sinop-Gerze } \\
\text { Bolalı }\end{array}$ & & $\mathrm{x}$ & $\mathrm{x}$ & & & Işın $1998,106 \mathrm{vd}$. \\
\hline 34 & Aktopraklık & $\begin{array}{l}\text { Sinop-Gerze } \\
\text { Bolalı }\end{array}$ & & $\mathrm{x}$ & & & & Işın 1998, 107. \\
\hline 35 & Dönbektepe & \begin{tabular}{|l|}
$\begin{array}{l}\text { Sinop-Gerze } \\
\text { Sarumsaklı }\end{array}$ \\
\end{tabular} & & $\mathrm{x}$ & & & & Işın 1998, 107. \\
\hline 36 & Cintepe & \begin{tabular}{|l|}
$\begin{array}{l}\text { Sinop-Gerze } \\
\text { Sanumsaklı }\end{array}$ \\
\end{tabular} & $\mathrm{x}$ & $\mathrm{x}$ & & & $\begin{array}{l}\text { Gec } \\
\text { Roma }\end{array}$ & Işıı $1998,107$. \\
\hline 37 & Alun Kaşı & $\begin{array}{l}\text { Sinop-Gerze } \\
\text { Sanmsaklı }\end{array}$ & & $\mathrm{x}$ & & & & Işın 1998, 107. \\
\hline 38 & Maltepe Sarım sak & $\begin{array}{l}\text { Sinop-Gerze } \\
\text { Sarımsak }\end{array}$ & & $\mathrm{x}$ & $\mathrm{x}$ & & Roma & Işın $1998,107 \mathrm{vd.}$ \\
\hline 39 & Kargalo & $\begin{array}{l}\text { Sinop-Gerze } \\
\text { Tilkilik } \\
\end{array}$ & & $\mathrm{x}$ & OTC? & & & Issın 1998, 108. \\
\hline 40 & Mercimek Tepe & $\begin{array}{l}\text { Sinop-Gerze } \\
\text { Tilkilik }\end{array}$ & & $\mathrm{x}$ & & & & Işıın 1998, 108. \\
\hline
\end{tabular}


TABLO 5

\begin{tabular}{|c|c|c|c|c|c|c|c|c|}
\hline \multirow[t]{2}{*}{ NO } & \multirow[t]{2}{*}{ tsim } & \multirow[t]{2}{*}{$\begin{array}{l}\text { II/ HLCE } \\
\text { KÖY }\end{array}$} & \multirow{2}{*}{ 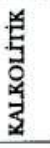 } & \multicolumn{2}{|c|}{ TUNÇ ÇAĞI } & \multirow[t]{2}{*}{$\begin{array}{l}\text { Demir } \\
\text { Cằ }\end{array}$} & \multirow{2}{*}{ 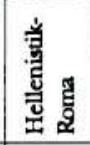 } & \multirow{2}{*}{ GÓNDERME } \\
\hline & & & & inc & OTCSTC & & & \\
\hline 41 & Görümcek & $\begin{array}{l}\text { Sinop-Gerze } \\
\text { Sanmsaklı }\end{array}$ & & $\mathrm{x}$ & & & & Işın 1998, 108. \\
\hline 42 & Karamkuru & $\begin{array}{l}\text { Sinop- } \\
\text { Yaykun }\end{array}$ & & $\mathrm{x}$ & OTC? & & & Işın 1998, 109. \\
\hline 43 & Tepecik & $\begin{array}{l}\text { Sinop-Ayancik } \\
\text { Taraksı }\end{array}$ & & $\mathrm{x}$ & & & $\begin{array}{l}\text { Gec } \\
\text { Roma }\end{array}$ & $\begin{array}{l}\text { Işu } 1990,245 ; 1 \text { şm vd. vd. } \\
1992,4 ; \operatorname{Is} \sin 1998,97 .\end{array}$ \\
\hline 44 & Ístefan & Sinop-Ayancak & & $\mathrm{x}$ & & & & 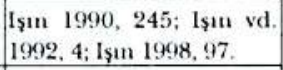 \\
\hline 45 & $\begin{array}{l}\text { Maltepe } \\
\text { (E.miryayla) }\end{array}$ & $\begin{array}{l}\text { Sinop-Boyalbat } \\
\text { Eniryayla- } \mathrm{N} \text { - } \\
\text { gaycayn }\end{array}$ & $\mathrm{x}$ & $\mathrm{x}$ & $\mathrm{x}$ & & Roma & $\begin{array}{l}\text { Işm 1990, 257-258; } 1 \text { şı } \\
\text { vd. 1992, 4; 1şı } 1998 . \\
\text { 105; Dönmez 2000, } 231 .\end{array}$ \\
\hline 46 & Uluköy -Cay & Sinop-Boyabat & $x$ & $\mathrm{x}$ & & & & Burney $1956,181$. \\
\hline 47 & Salar Kalesi & Sinop-Broyabat & & $\mathrm{x}$ & & & $\begin{array}{l}\text { Helle - } \\
\text { nis-- } \\
\text { Rona }\end{array}$ & 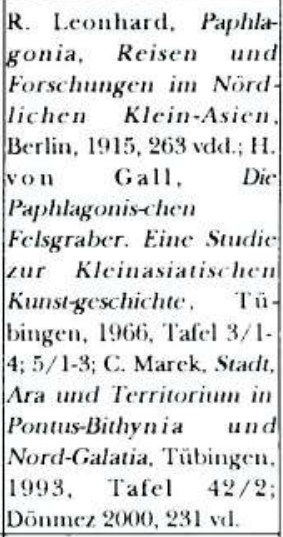 \\
\hline 48 & Parar Tepesi & $\begin{array}{l}\text { Sunop-Boyabat } \\
\text { Erkeç }\end{array}$ & & $x$ & & & & Dönmez 2000, 232. \\
\hline 49 & Boyalı Ikiztepe I & $\begin{array}{l}\text { Sinop-Boyabat } \\
\text { Boyalt }\end{array}$ & & $\mathrm{x}$ & OTC: & GDC: & & Dönmez 2000, 232. \\
\hline 50 & Boyalı Ikiztepe II & $\begin{array}{l}\text { Surop -Boyabat } \\
\text { Boyali }\end{array}$ & & $\mathrm{x}$ & OTC & GDC & & Dồumez. 2000, 232. \\
\hline 51 & Cukurhan Kale & $\begin{array}{l}\text { Sinop-Boyabat } \\
\text { Cukurhan }\end{array}$ & & & & $\mathrm{x}$ & $\begin{array}{l}\text { Helle- } \\
\text { nis.- } \\
\text { Roma }\end{array}$ & Işı 1998, 105. \\
\hline 52 & Dodurga & $\begin{array}{l}\text { Sinop-Boyabat } \\
\text { Dodurga }\end{array}$ & & $x$ & & $\mathrm{x}$ & $\begin{array}{l}\text { Helle- } \\
\text { nis.- } \\
\text { Roma }\end{array}$ & Iş1n 1998.105. \\
\hline 53 & Bayram Tepesi & $\begin{array}{l}\text { Sunop- } \\
\text { Saraydüzü }\end{array}$ & & $\mathrm{x}$ & & & & Döинсс 2000, 232. \\
\hline
\end{tabular}




\section{BIBLIYYGRAFYA*}

AKARCA, A.

1987: Şehir ve Savunması, Ankara.

AKURGAL, E.

1956: "Sinop Kazıları-Die Ausgrabungen von Sinope", TAD, VI-1, 4761.

AKURGAL, E.- L.BUDDE

1956: $\quad$ Vorlaufige Bericht Über Die Ausgrabungen in Sinope, Ankara.

ALKIM, U.B.-H.ALKIM-Ö.BILGI

1988: $\quad$ Íkiztepe I. Birinci ve Íkinci Dönem Kazıları The First and Second Seasons' Excavations (1974-1975), Ankara.

BILGEN, A.N.

1999: “Kastamonu-Kınık Kazısı 1994-1995 Metalurjik Buluntuları”, An.Ar., XV, 269-293.

BİLGİ, Ö.

1990:

"Bafra-İkiztepe Kazılarının Işığında Samsun Bölgesinin Protohistoryası", Tarih Boyunca Karadeniz Kongresi Bildirileri, II/1, 1988, 1-3.

1994: Samsun Müzesi Protohistorik Çağ Silahları ve Orta Karadeniz Bölgesi Maden Sanatu Hakkında Yeni Gözlemler", TTKong., XI, 253-268.

1998: M.Ö. 2. Binyılda Orta Karadeniz Bölgesi", III. Uluslararası Hititoloji Kongresi Bildirileri, Çorum 16-22 Eylül 1996, Ankara, 63-75.

1999 a: İkiztepe'de Ele Geçen Son Buluntuları Işı̆̆ında Orta Karadeniz Bölgesi Protohistorik Çağ Maden Sanatı Hakkında Yeni Gözlemler", TTKong., XII/1, 1994, 41-50, Levha 17-28.

1999 b: "İkiztepe in the Late Iron Age", AS, Anatolian Iron Ages, ed. A. Çilingiroğlu- R.J. Matthews, 4, 27-54.

• Bibliyografya seçme eserlerden oluşmuktadır. Diğer eserler dipnotlarda verilmiştir. 
1999 c: Karadeniz Bölgesi Kıyı Kesimi İlk Tunç Çă̆ı Mimarisi”, Çağlar Boyunca Anadolu'da Yerleşim ve Konut Uluslar arası Sempozyumu, İstanbul, 63-74.

BOYSAL, Y.

1958:

"Sinop'un En Eski Buluntuları ve Kolonizasyonu Hakkında", $T A D$, VIII-2, 23-29.

BURNEY, C. A.

1956: $\quad$ "Northern Anatolia Before Classical Times", AS, VI, 179-203. ÇINAROĞLU, A.

1991: "Kastamonu Kökenli Bir Grup Hitit Gümüş Eseri", Müze/Museum, 4 (1990-91), 53-58.

DOONAN, O.- A. GANTOS- D. SMART- F. HIEBERT

1998: "Survey of Sinop Province, Turkey, 1997", paper delivered at AIA Annual Meeting, Chicago, 12/97. Abstarct forthcoming in AJA, 102, 367.

1999: $\quad$ "Sinop İli Yoğun Alan Araşturması, 1997", AST, XVII-II, 359371.

DOONAN, O.- A. GANTOS- F. HIEBERT- A. YAYCIOĞLU- M. BESONEN

2000: "Sinop Bölgesel Arkeoloji Araşturması 1998: Karasu Vadi Araşurması", AST, XVII-2, 345-356.

DÖNMEZ, Ş.

2000:

"Sinop-Samsun-Amasya İlleri 1998 Yüzey Araşturması", AST, XVII-2, 229-244.

EMRE, K.- A. ÇINAROĞLU

1993:

"A Group of Metal Hittite Vessels from Kınık- Kastamonu", Nimet Özgüç'e Armağan, Ankara, 675-713.

ERZEN, A.

1956:

"Sinop Kazısı 1953 Yilı Çalışmaları", TAD, VI-1'den ayrıbasım, 3-6, Levha XXVIII-XXXI.

FORRER, E.

1927:

"Ergebnisse Einer Archaologischen Reise in Kleinasien", Mitteilungen Der Deutschen Orient-Gesellschaft, 65, 27-43. 
FRENCH, D. H.

1988:

"Roman Roads and Milestones of Asia Minor 1987", AS, The Years Work, XXXVIII, 8-10.

IŞIN, M. A.

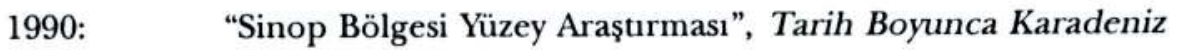
Kongresi Bildirileri, II/1, 241-277.

1991: “Kocagöz Höyük'te Bulunan Tek Kulplu Kupalar”, TAD, XXIX, 177-191.

1998: Sinop Region Field Survey”, Anatolia Antiqua/Eski Anadolu, VI, 95-139.

IŞIN, M. A.- İ. TATLICAN- M. IŞIN

1992: $\quad$ Sinop, Ankara.

KOÇAK, Ö.

1993: $\quad$ Eskiçağ Tarihinde Sinope, (Yayımlanmamış Yüksek Lisans Tezi), İstanbul.

2000: $\quad$ M. Ö. II. ve I. Bin Yllarda Orta Karadeniz Bölgesi'nin Jeopolitik ve Sosyopolitik Yapısı, (Yayınlanmamış Doktora Tezi), İstanbul.

KÖKTEN, K.-N.ÖZGÜÇ-T.ÖZGÜÇ

1945: "1940 ve 1941 Yilında Türk Tarih Kurumu Adına Yapılan Samsun Bölgesi Kazıları Hakkında İlk Kısa Rapor”, Belleten, IX/35, 361-400, Levha LXIII-LXXIV.

LEAF, W.

1916: "The Commerce of Sinope", JHS, XXXVI (1916), 1-15.

ORTHMANN, W.

1963: Die Keramik der Frühen Bronzezeit aus Interanatolien, Berlin.

ÖZBAL, H.- A. ADRIAENS- B. EARL- B. GEDIK

2000: Samsun-Amasya-Tokat İlleri Yüzey Araştırmaları", ArkST., XV, 47-54.

ÖZDOĞAN, A.- C. MARRO- A. TIBBET- C. KUZIJCUOĞLU

2000: "Kastamonu Yüzey Araştırması 1998 Yılı Çalışmaları”, AST, XVII-2, 41-56. 
ÖZGÜÇ, T.

1948:

"Samsun Hafriyatının 1941-1942 Ylı Neticeleri", TTKong., 3, 1943, 393-419.

STOOP, M.V.

1978: “Ancient Armene and Its Harbour", Anatolica, VI, 1977-1978, 282-318.

WYCHERLEY, R.E.

1986: Antik Çağda Kentler Nasıl Kuruldu?, çev. N.Nirven-N.Başgelen, İstanbul.

\section{KISALTMALAR}

AJA American Journal of Archaeology, Baltimore, $1885 \mathrm{vd}$.

An.Ar. Anadolu Araştırmaları, İstanbul, $1955 \mathrm{vd.}$

AS Anatolian Studies, Journal of the British Instituteof Archeology at Ankara, London, $1951 \mathrm{vd.}$

AST T.C. Kültür Bakanlığı Anıtlar ve Müzeler Genel Müdürlüğü, Araşturma Sonuçlanı Toplantssı, 1983 vdd.

Belleten Türk Tarih Kurumu, Belleten, 1937 vd.

DTCFD Ankara Üniversitesi Dil ve Tarih-Coğrafya Fakültesi Dergisi, Ankara, 1942 vd.

JHS Journal of Hellenic Studies

TAD Türk Arkeoloji Dergisi, Ankara, 1950 vd.

TTKong. Türk Tarih Kongresi Raporları, Ankara, 1932 vd.

Diğer Kısaltmalar:

İTÇ: İlk Tunç Çă̆

OTÇ: Orta Tunç Çăg

STÇ: $\quad$ Son Tunç Çă̆

DÇ: Demir Çă̆ı

GDÇ: Geç Demir Çă̆ 


\section{HARITA, LEVHA VE PLANLARIN LISTESI}

\section{HARITA 1}

Orta Karadeniz Bölgesi'nin topografik durumu (S. Gözenç- N. Günal, "Türkiye'nin Coğrafi Bölgelerinde Kır-Şehir Nüfusu Ayrımı ile Şehir Nüfusunun 1/ 200.000 Ölçekli Haritada Yükselti Kademelerine Göre Tespiti”, I.Ü. Deniz Bilimleri ve Coğrafya Enstitüsü Bülten, 3/4, 1987 (1988), 27-37, topoğrafi haritası).

\section{HARITTA 2}

Harita Genel Müdürlüğü, Zonguldak 1:500.000, 333 C Harita Paftası, Ankara; Harita Genel Müdürlüğü, Samsun 1:500.000, 324 D Harita Paftası, Ankara.

\section{LEVHA I}

1. Sinop-Merkez Lala Tavukçuluğu'nda yer alan Çimbektepe Yerleşmesi (Işıı vd. 1992, 6).

2. Sinop-Erfelek Hasandere'de yer alan Halil Usta Tepesi Yerleşmesi (Işıı vd. 1992, 6).

\section{LEVHA II}

1. Sinop'un hemen girişindeki Pervane Dede Tepesi'nden Sinop'un güneyinde yer alan Aşağı Liman.

2.Sinop Yarımadası boynunun kuzeyinden Yukarı Liman.

\section{LEVHA III}

1. Sinop'un hemen girişindeki Pervane Dede Tepesi'nden Sinop Yarımadası ile Kuzey ve Güney Limanları.

2. Sinop'un hemen girişindeki Pervane Dede Tepesi'nden modern Samsun-Gerze yolu, Akliman ve Hamsalos Burnu.

\section{PLAN}

1. Wycherley 1986, Şekil 3, Miletos.

2. Y. Garlan- D. K. Tezgör, "Prospection d'ateliers d'amphores et de Ceramiques de Sinope", Anatolia Antiqua- Eski Anadolu, IV (1996), 325-334, Figür 1.

3. Işın vd. 1992, 50. 13. yüzyıl Selçuklu onarımından sonra Sinop kale surlar1. 
TABLO 1

\begin{tabular}{|l|c|c|c|c|}
\hline & Kalkolitik & ITC & OTC/STC & DC \\
\hline SiNOP & 15 & 47 & 13 & 7 \\
\hline$\%$ & 18,2 & 57,3 & 15.8 & 8.5 \\
\hline
\end{tabular}

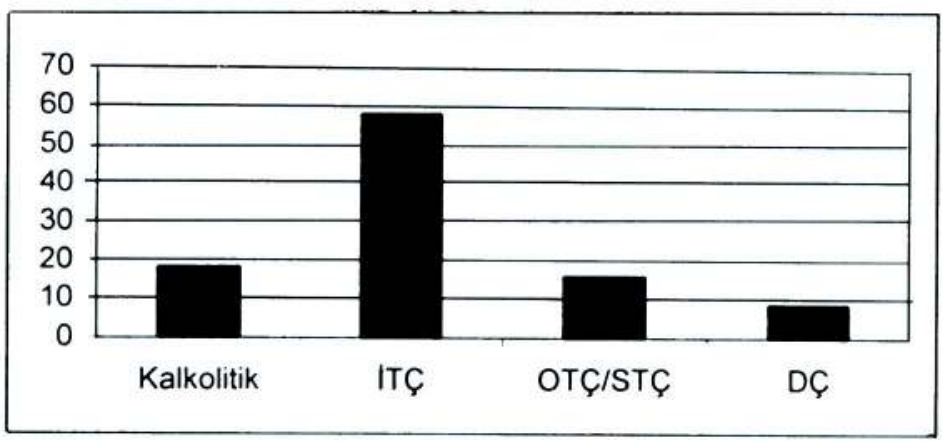

TABLO 2

\begin{tabular}{|c|c|c|c|c|c|c|c|c|c|}
\hline & 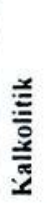 & $E$ & 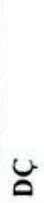 & 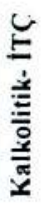 & 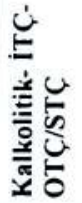 & 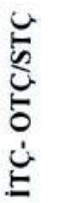 & 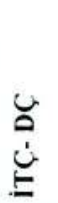 & : & $\frac{\sum}{\grave{j}}$ \\
\hline SINOP & 1 & 22 & 2 & 10 & 4 & 6 & 2 & 3 & 50 \\
\hline$\%$ & 2 & 44 & 4 & 20 & 8 & 12 & 4 & 6 & 100 \\
\hline
\end{tabular}

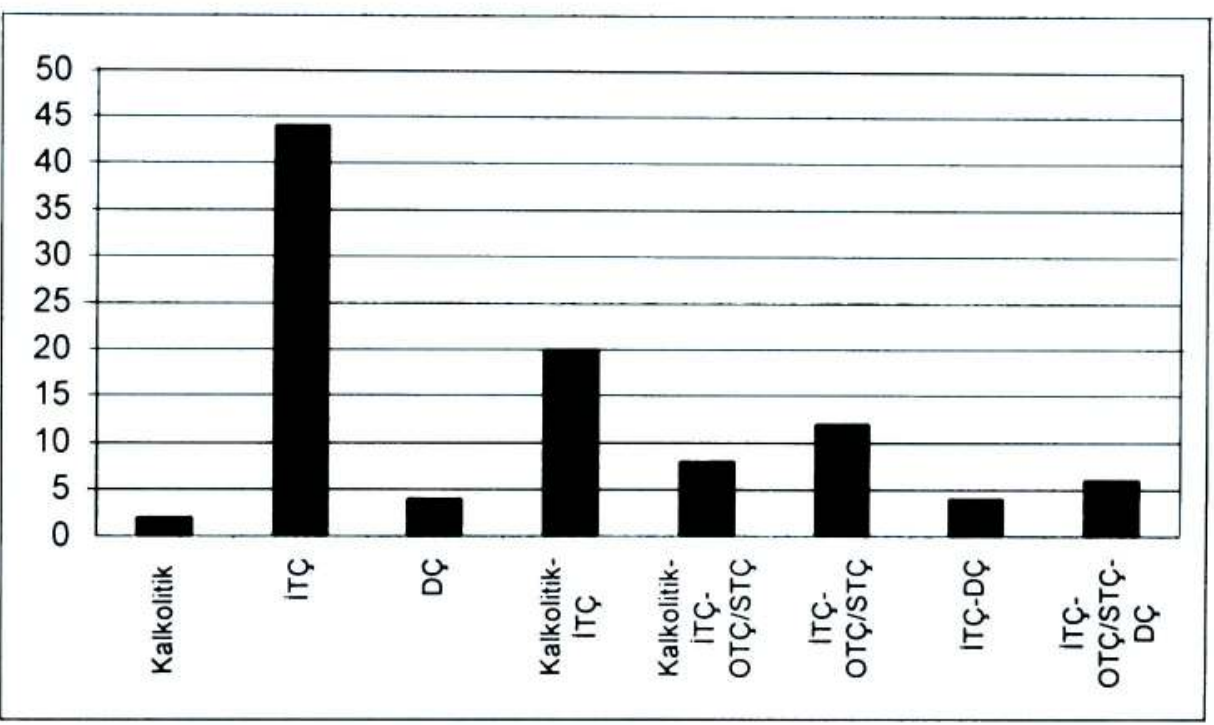


Özdemir Koçak

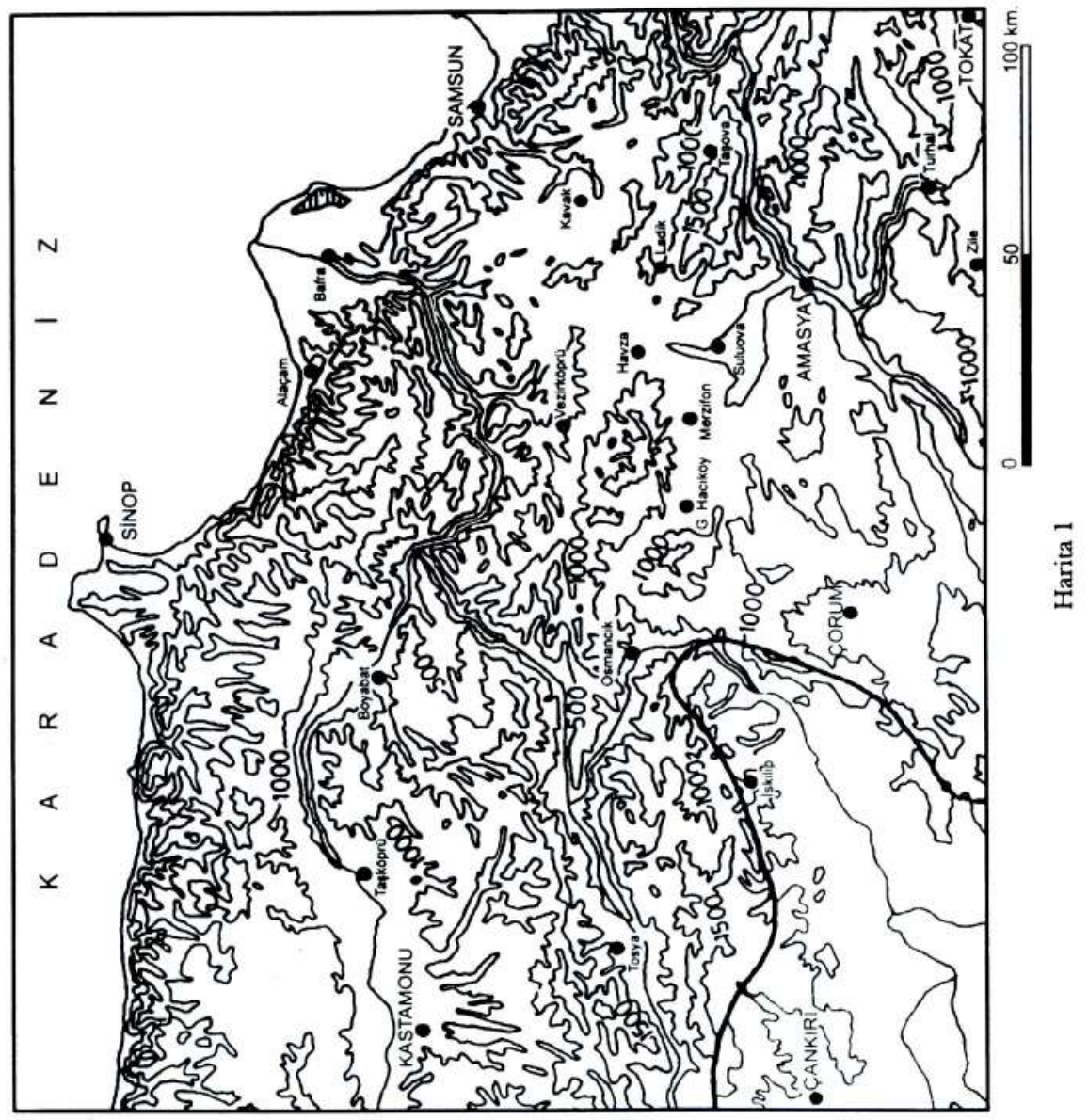




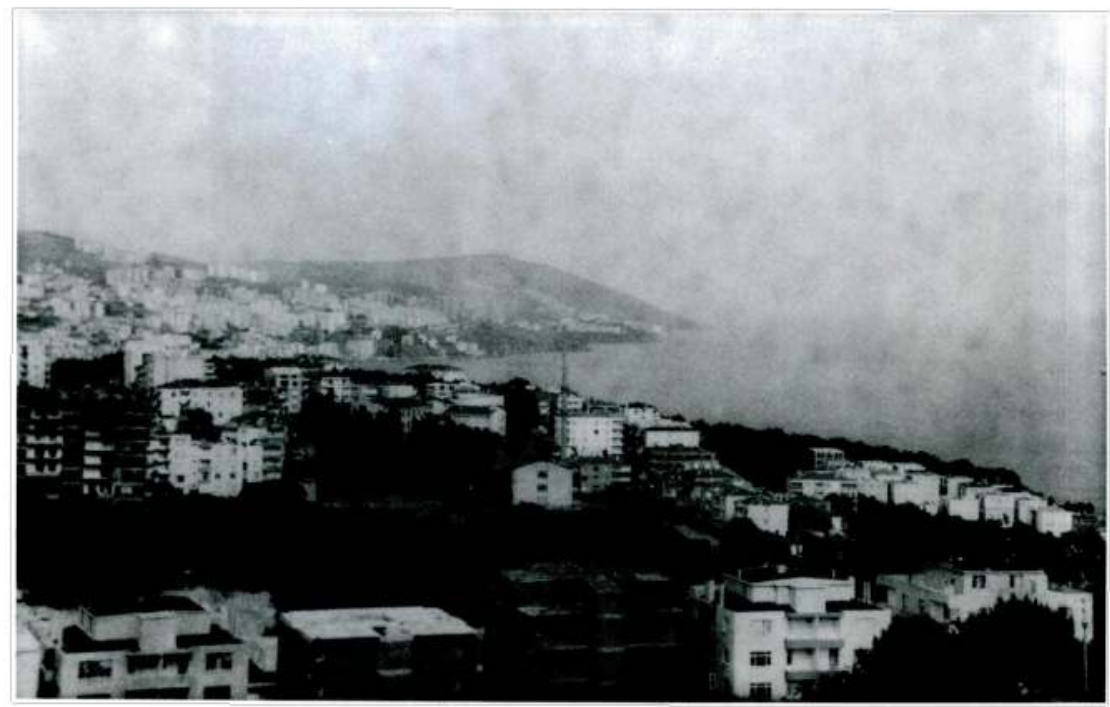

1. Sinop'un hemen girişindeki Pervane Dede Tepesi'nden Sinop'un güneyinde yer alan Aşağı Liman.

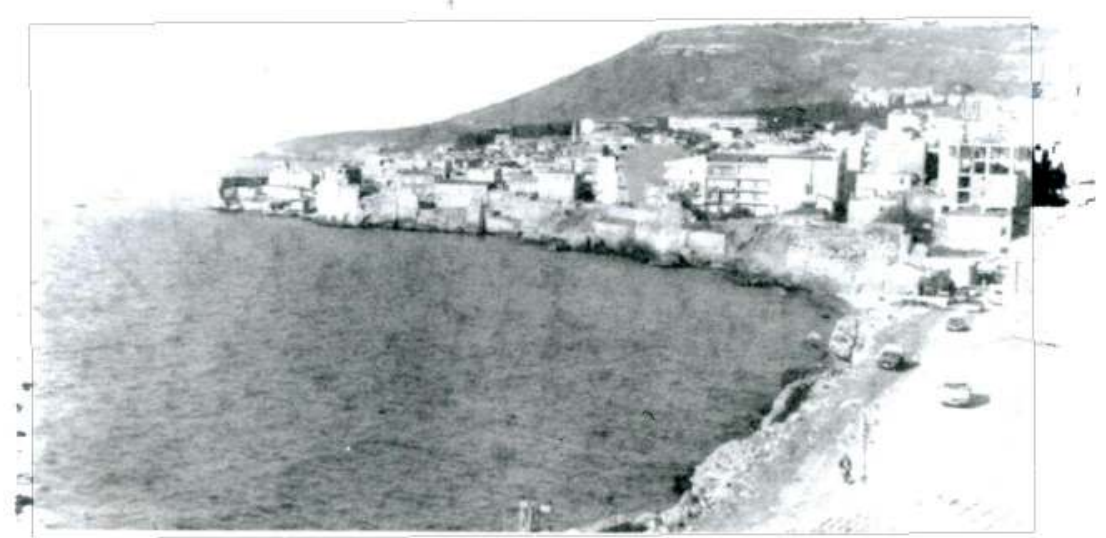

2.Sinop Yarımadası boynunun kuzeyinden Yukan Liman. 


\section{Levha 3}

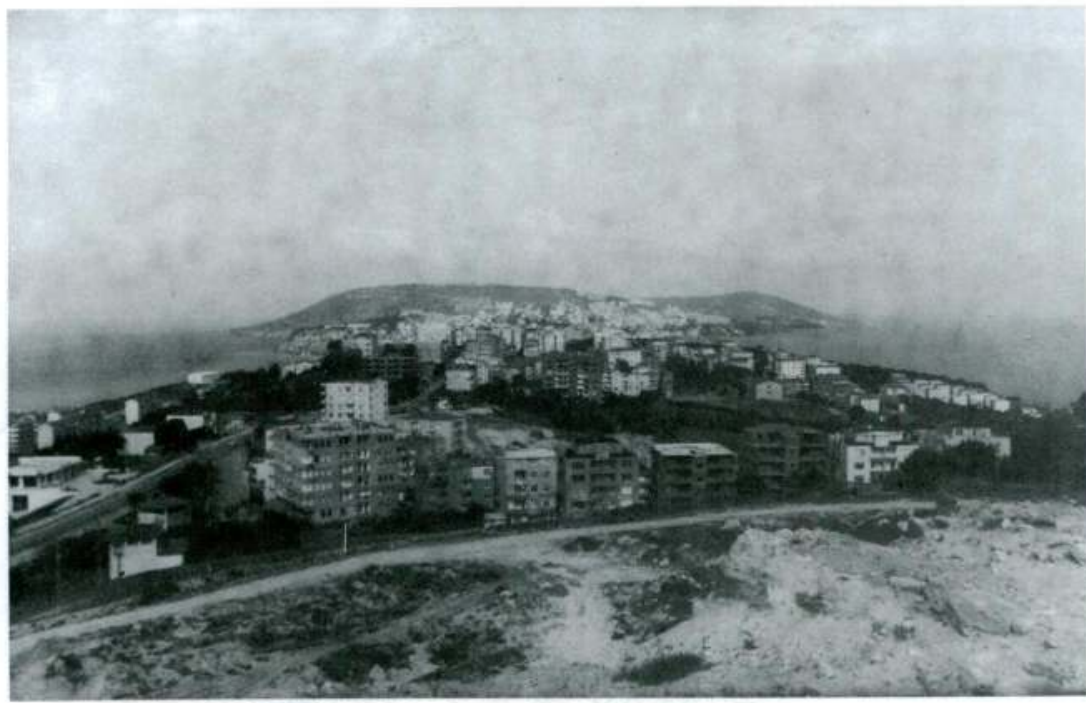

1. Sinop'un hemen girişindeki Pervane Dede Tepesi'nden Sinop Yarımadası ile Kuzey ve Güney Limanlarn.

2. Sinop'un hemen girişindeki Pervane Dede Tepesi'nden modern Samsun-Gerze yolu, Akliman ve Hamsalos Burnu. 
Özdemir Koçak

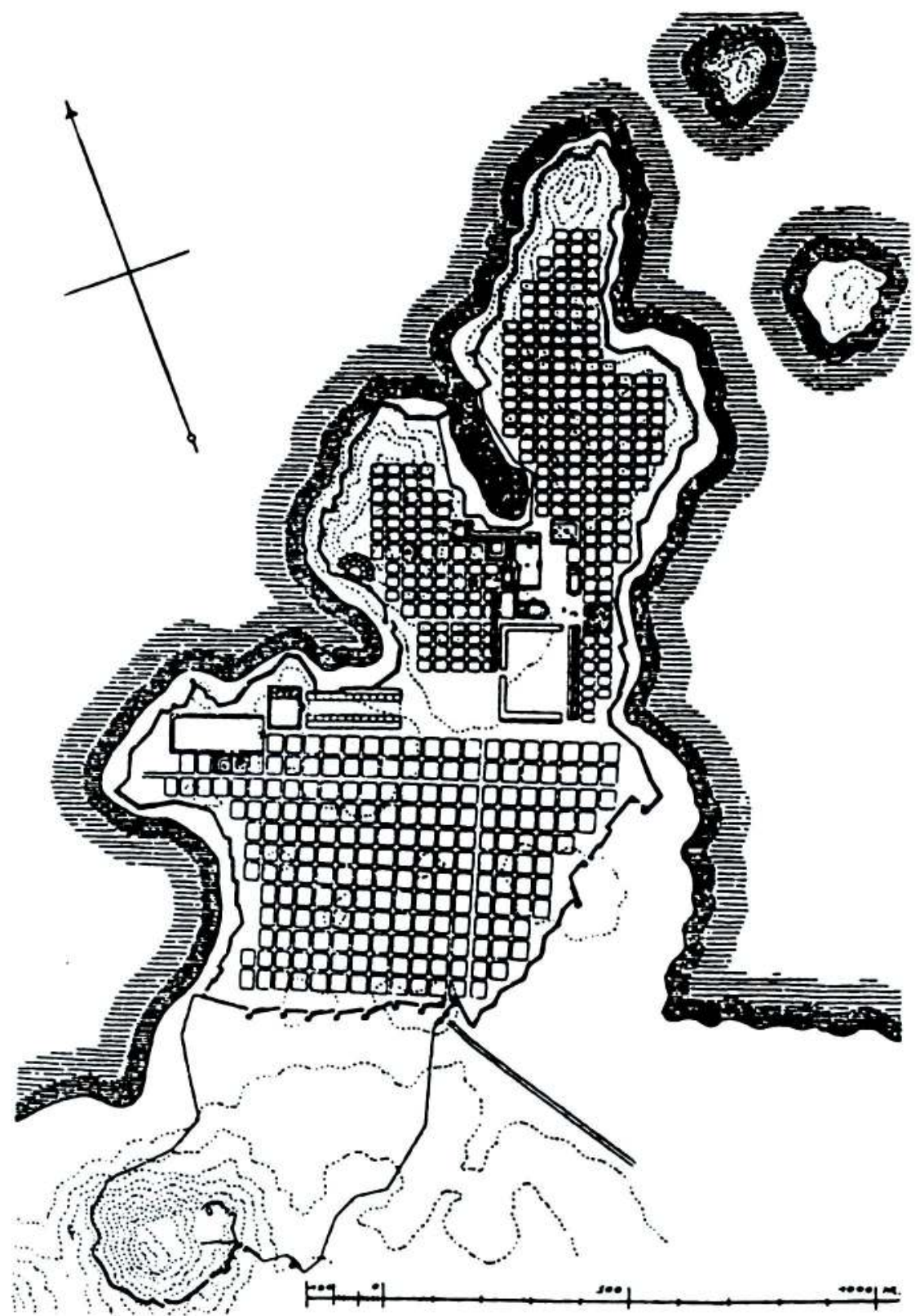

1. Wycherley 1986, Sekil 3, Miletos. 
Özdemir Koçak

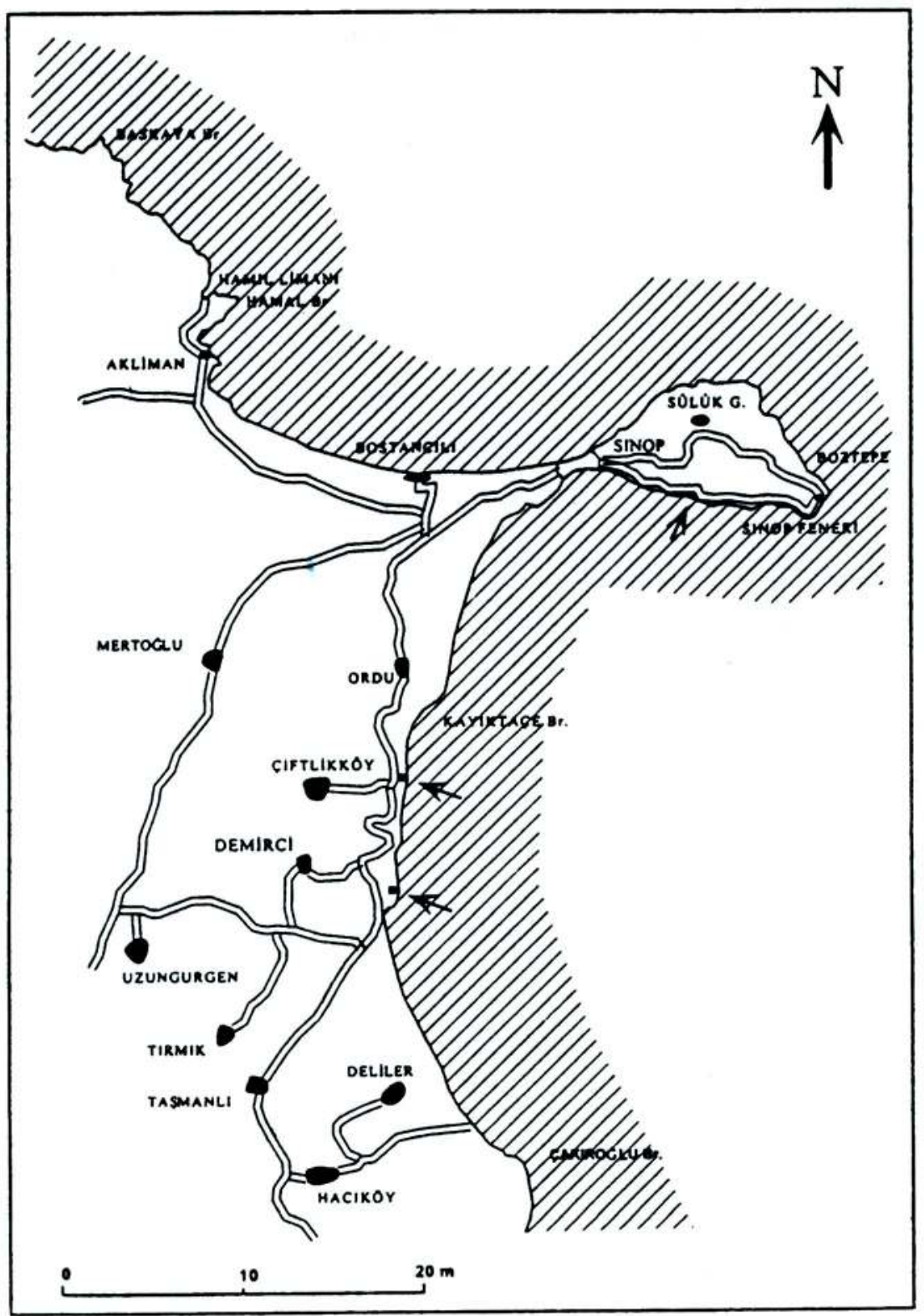

2. Y. Garlan- D. K. Tezgōr, "Prospection d'ateliers d'amphores et de Ceramiques de Sinope", Anatolia Antiqua- Eski Anadolu, IV (1996), 325-334, Figür 1. 


\section{Özdemir Koçak}

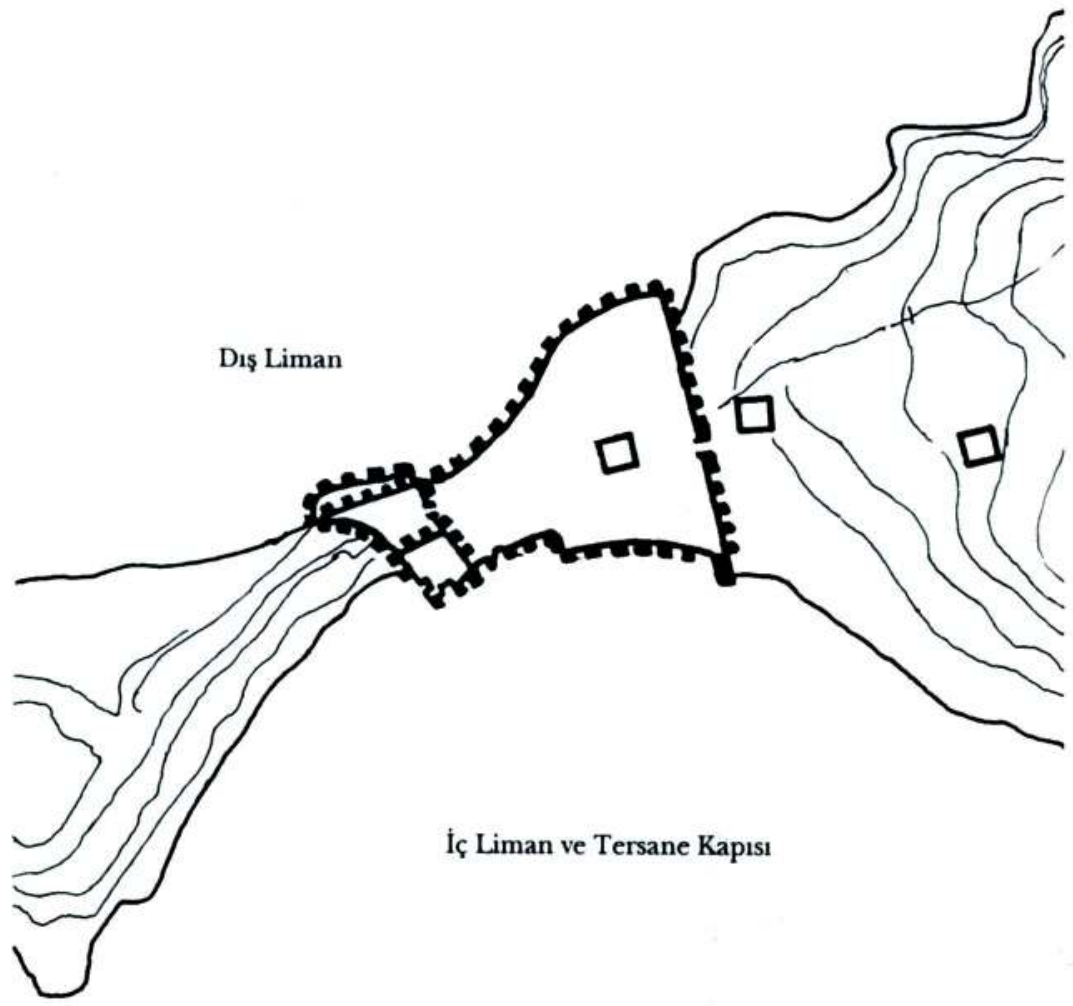

3. Işın vd. 1992, 50. 13. yüzyıl Selçuklu onarımından sonra Sinop kale surları. 